LSE 'Europe in Question’ Discussion Paper Series

\title{
Beyond the crisis: EMU and labour market reform pressures in good and bad times
}

Vassilis Monastiriotis \& Sotirios Zartaloudis

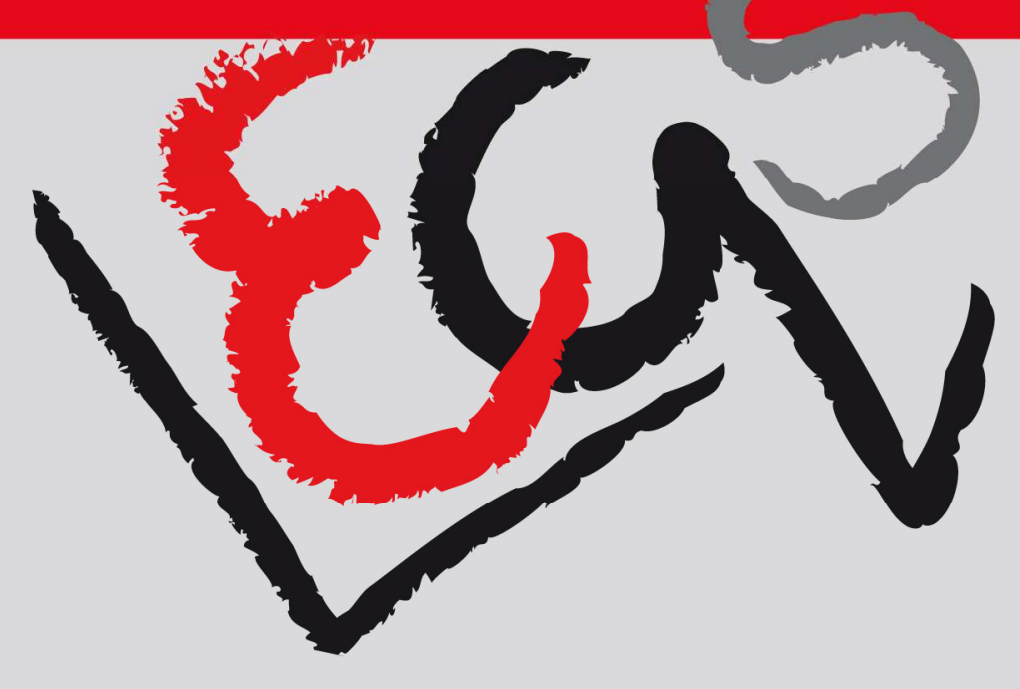




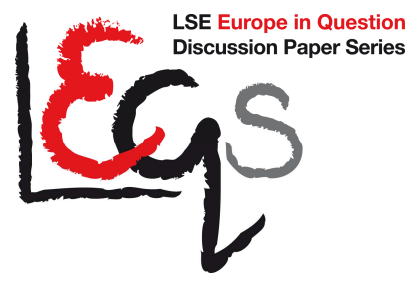

\section{Editorial Board}

Dr. Joan Costa-i-Font

Dr. Vassilis Monastiriotis

Dr. Jonathan White

Ms. Katjana Gattermann

All views expressed in this paper are those of the author and do not necessarily represent the views of the editors or the LSE.

(C) Vassilis Monastiriotis \& Sotirios Zartaloudis 


\title{
Beyond the crisis: EMU and labour
}

\section{market reform pressures in good}

\section{and bad times}

\section{Vassilis Monastiriotis* \& Sotirios Zartaloudis*}

\begin{abstract}
There is a widespread perception among the public and policy-makers that EMU carries oneway pressures for enhanced flexibility in the labour market. We discuss the theoretical basis of this by examining four mechanisms through which the establishment of the common currency and the functioning of EMU can impact on the labour markets, both within the Eurozone and of the New Member States. We argue that the theory and empirics of the link between EMU and labour market flexibility are not conclusive, leaving room for varying degrees of, and directions for, the (de)regulation of national labour markets. This discretion is partly reflected in the experience of labour market reforms in the Eurozone. An examination of the institutional framework for employment policies in the EU further corroborates the conclusion that EMU does not restrict, but rather puts on the agenda, the active exploration of policy options aimed at strengthening the resilience and adaptability of the European economy as well as its quality, fairness and competitiveness. We argue that this is no different today, during or after the crisis, than it was 'before it all started'.
\end{abstract}

\footnotetext{
* London School of Economics and Political Science European Institute, Houghton St, London WC2A 2AE, UK Email: v.monastiriotis@lse.ac.uk; s.zartaloudis@lse.ac.uk
} 


\title{
Table of Contents
}

\author{
Abstract
}

1. Introduction

2. EMU and labour markets: theory and policy issues

2.1. The theory of (sub-)optimal currency areas

2.2. Monetary policy and the shift of the 'pivotal triangle' of macro-economic policy

2.3. The political economy of wage restraint - the experience of Maastricht

2.4. Fiscal policy and labour markets

3. Transnational regulation and cooperation in the field of employment in the EU

3.1. The framework for employment policies in the EU

3.2. The European experience of reforms

4. EMU enlargement and the challenges ahead

4.1. Pressures on the labour markets of the acceding States

References 


\section{Beyond the crisis: EMU and labour}

\section{market reform pressures in good}

\section{and bad times}

\section{Introduction}

The creation of the Economic and Monetary Union (EMU) in Europe was a critical junction in the functioning of the European Union's (EU) institutions and of the national economies participating in the project. Among the main spillovers of the creation of the common currency are the further deepening of economic integration (enhanced trade, price transparency, competition, etc.), the strengthening of the process of political integration (with the emergence of forms of fiscal cooperation and, more recently, financial regulation), the transformation of the structures of economic governance and cooperation (establishment of independent supra-national institutions, outside the remit of the Commission), and the enhancement of EU's international role (financial and political). Inevitably, these developments alter significantly the experiences of the European public within the EU: as citizens (since the public is further detached from the control of economic policy), as consumers (with the creation of an enlarged market with greater product variety and price stability and transparency), as producers (greater competition, enhanced market access and a larger market) and, crucially, as employees (with the increased pressures for the re-organisation of labour relations). Following, a vibrant debate has emerged regarding the changing character of the EU and whether the ongoing integration process enhances or weakens EU's social dimension.

Although the current crisis (not only the global economic one but also the coordination/credibility problems that have emerged in the Eurozone with the Greek 
fiscal crisis) may have reduced the salience of this debate, we believe that this remains central to European matters and, moreover, better understood outside the lenses of the crisis. Indeed, we would argue that the crisis has accentuated the key parameters in the issues surrounding the 'European model' (essentially, questions of rules versus discretion, of fiscal stimuli versus stabilisation, of free markets versus economic governance, of price stability versus 'jobs \& growth', and so forth) but it has not altered the nature of the problem. In a way, this is because questions concerning the model of economic governance in the Eurozone, at least those aspects of it that emphasised the importance of 'less state' and market deregulation, were always framed in relation to (an asymmetric) crisis. ${ }^{1}$ But as the crisis has shown that in 'bad times' adherence to rules (for fiscal discipline as well as for bail-outs, including by Central Banks) can be flexed ${ }^{2}$, especially when market adjustments become too costly (in terms of credit defaults, bankruptcies and unemployment), it has also highlighted that the regulatory pressures emanating from the European integration project, and from EMU in particular, are not unidirectional nor unequivocal - and they are definitely not insurmountable.

This is exactly the point we address in this paper, focusing on the area of labour markets, as one of the areas where the pressures for deregulation have been more prevalent. We depart from the current debates about fiscal and structural adjustment in a time of crisis, which naturally frame the issue with reference to legitimisation and enforcement ('window of opportunity'), and instead focus on the very fundamental question of what necessitates reforms in EMU. To do so, we examine a range of arguments and theoretical propositions, both for and against, that have been proposed in the literature. We distinguish four types of pressures that monetary convergence and the common currency apply to the labour markets of current and prospective members of EMU. These are as follows: (a) pressures relating to the

\footnotetext{
${ }^{1}$ Note that for a long time the Eurozone appeared to be capable of insulating its members from the global crisis and the latter only became a Eurozone problem when its effects became asymmetric, as different transmission mechanisms were activated in different countries (e.g., a decline in exports in Germany, a capital drainage in Ireland, the housing bust in Spain, the solvency problems in Greece, etc).

${ }^{2}$ Although, admittedly, this happened less so in the Eurozone than in other places, including the USA (Schelkle, 2009).
} 
process of monetary convergence and the associated convergence criteria (Maastricht effect), (b) pressures applied to states belonging to sub-optimal currency areas (OCA effect), (c) pressures resulting from the shift of the centre of gravity of economic policies in EMU ('pivotal triangle' effect), and (d) pressures arising from the model of fiscal governance in EMU (SGP effect). ${ }^{3}$

It is often overlooked, and thus worth noting, that these pressures do not operate in a policy vacuum. Indeed, domestic politics and European policy processes shape the influences of these pressures and they restrict and/or facilitate the national responses to them. A distinctive mechanism within this framework is the European Employment Strategy (EES). The EES aims at improving, and to some extent harmonising, the functioning of EU labour markets (inside and outside EMU) through the establishment of a common framework of national labour market interventions, which can be compatible with, and promote the objectives of, the Lisbon Strategy. Although, strictly speaking, the EES is independent of EMU, it is nevertheless inextricably linked with the process of monetary integration in Europe, since its main aim is to provide common solutions to problems of competitiveness, adjustability and (e)quality, which the EU faces in the post-EMU era.

We discuss these common solutions and, more generally, the institutional and operational issues arising from EU's economic governance in the field of employment policy, later in the paper. We start our discussion, in section 2, with a detailed examination of the mechanisms through which, according to theory, the aforementioned pressures and effects are activated - and examine their policy implications. Our starting point is the Optimum Currency Area (OCA) theory, which is the main analytical framework under which the wider pressures on the labour

\footnotetext{
3 In this sense, our paper does not cover another dimension of the issue, that has been extensively discussed in the literature, concerning the role of EMU in facilitating (or strangling) reforms by legitimising them externally and conditioning the relevant policy options of national governments. In the literature this dimension is displayed in various forms, such as "vincolo esterno" or external empowerment (Dyson and Featherstone, 1999), "tying one's hands" (Giavazzi and Pagano, 1988), shrinking of the "set of policy options" (Schelkle, 2004), "blameshifting" or a "scapegoat" mechanism (Begg, 2002), or the "back against the wall" (Alesina et al, 2006) and "there is no alternative" (Bean, 1998) theses. We refer to these aspects selectively in various parts of the paper, but we do not analyse them in detail as a separate dimension of this debate, because our focus is on why reforms (and which types of reforms) are necessary, whereas the above aspects concern mainly the question of whether reforms are possible.
} 
Beyond the crisis

market in the post-EMU era are conceptualised. We then focus on the impact that the process of monetary integration and the resulting shift in the balance between monetary policy and wage bargaining have on the regulation and functioning of labour markets (and of collective bargaining in particular). We close the second section with an analysis of the fiscal and other institutional constraints that are applied on the operation and regulation of labour markets in EMU. In section 3 we turn to the EU's institutional framework for employment policy coordination and to the labour market reforms that have been followed by the EMU countries in the last fifteen years. In particular, we examine the extent to which EU employment policy constitutes a mechanism that consolidates and institutionalises the flexibilisation processes that may be triggered by EMU or, rather, a social response to such processes; and support empirically our argumentation with a brief review of the member states' reform record in the field of employment policy, drawing on existing evidence in the literature. Then, in section 4, we examine the issues that arise for the current and prospective EMU Member States from the future enlargement waves of the Eurozone. We conclude the paper with some final thoughts on the overall assessment of the effects of EMU on labour markets in Europe.

\section{EMU and labour markets: theory and policy issues}

\subsection{The theory of (sub-)optimal currency areas}

A central point of the discussion about the labour market effects of EMU is the Optimum Currency Area theory, as originally formulated by Robert Mundell (1961) and subsequently enriched by McKinnon (1963), Kenen (1969), Mundell (1973) and others (see DeGrawue, 2006). Mundell's point of departure was the premise that the adoption of a common currency (and of a common monetary policy) by a group of countries will be welfare improving if at least one of the following conditions holds true: the economic cycles of participant countries are fully synchronised; an 
integrated system of fiscal transfers is put in place across the participating countries; or market adjustment mechanisms operate efficiently at the national and supranational levels. ${ }^{4}$

What is the logic of these conditions? By irrevocably fixing their exchange rates and adopting a common monetary policy, national authorities lose their control over the exchange rate as a main instrument for adjustment to internal (inflation) and external (trade deficits) imbalances. Outside a monetary union, if a country is hit by an asymmetric (country-specific) shock -for example, a fall in demand-the country can restore demand by reducing its interest rates: this will stimulate domestic demand by lowering the costs of production and of borrowing; but it will also lead to a depreciation of its currency, thus also increasing external demand (as the country's products become cheaper and thus more competitive). If, because of the common currency, the country experiencing the shock cannot use discretionary monetary policy measures (depreciation, changes in interest rates), then this adjustment mechanism becomes unavailable and, therefore, other mechanisms should be put in place to restore equilibrium. If, however, the shock is common to all countries participating in the monetary union, then the interest rate adjustment can still function as in the case of a single country with independent monetary policy. It follows that the importance of alternative adjustment mechanisms is directly proportionate to the likelihood of asymmetric shocks within a monetary union. The more synchronized the participating economies, the less likely it is that they will have diverging preferences on monetary policy. ${ }^{5}$

If, nevertheless, an asymmetric shock does occur inside a monetary union, theoretically this could be addressed by a transfer of resources from the economy that is not affected to the one experiencing the shock. This is the main adjustment

\footnotetext{
${ }^{4}$ It is worth mentioning here that each of these conditions, when fully met, is a sufficient condition in itself, in the sense that meeting one renders the other two unnecessary. This substitutability, which makes the issue of managing the common currency an issue of choice between fiscal coordination and labour market reform, is often overlooked, especially in policy debates.

5 Beyond the parameter of synchronicity, other important parameters strengthening the synchronicity of two economies include the extent of economic integration (so that shocks are transmitted easily and fast across countries) and the extent of economic diversification (so that the economies do not depend disproportionately on too few sectors).
} 
mechanism against asymmetric shocks in all national economies: if, for example, an exogenous shock hits a country's tourism industry, thus affecting disproportionately those regions in the country specialising in tourism, an automatic process of fiscal transfers is activated, in the form of transfer payments (e.g., unemployment benefits) and lower tax receipts (due to declining economic activity). In most cases, this automatic process will also be accompanied by activist measures to support economic activity in the ailing region, such as additional public investment, direct subsidies to industry, tax breaks, etc. In this way, the region hit by the shock will be able to recover even if its prices (including wages) and basic quantities (number of firms and labour supply) do not adjust (and assuming that the region does not have the ability to exercise independent monetary policy).

To the extent that none of these conditions (synchronicity, transfers, adjustability) are fully met, monetary integration requires these conditions to be considered complementarily. In other words, when economic cycles are not fully harmonised and transfer mechanisms are not fully developed, as in EMU, the functioning of adjustment mechanisms, especially in the labour market, obtains greater salience. It is on this basis that the debate about the (de)regulation of labour markets in Europe is directly linked to the establishment of EMU - as the latter appears to require the strengthening of the functioning of adjustment mechanisms in the Eurozone. ${ }^{6}$ In the labour market these mechanisms are translated largely into two factors: labour mobility and wage flexibility. ${ }^{7}$

Labour Mobility. Principally, the relevant debate focuses on the extremely low mobility within the Euro area, as a result of a combination of exogenous factors (e.g., linguistic and cultural barriers) and factors that are endogenous to policy (e.g., lack

\footnotetext{
${ }^{6}$ As regards to the broader issue of structural reform this argument has been made known as TINA (There Is No Alternative) - see on Bean (1998) and IMF (2004).

7 It should be noted that labour market adjustment is only one of a set of possible adjustments in the economy, as equilibration may also be achieved with flexibility in the product and capital markets. For example, under full capital mobility (and perfect financial markets) asymmetric shocks lead to a reallocation of capital (redirection of investment) in sectors and areas not affected by the shock, where profitability is comparatively higher. Even if there are lags in the functioning of this mechanism (e.g., non-convertibility of physical capital in the short-run), the flexible adjustment of product prices (which is partly enhanced due to greater pricetransparency achieved through the use of a common currency) is sufficient to absorb the asymmetric shocks, making labour flexibility unnecessary (Burda, 1999).
} 
of harmonisation in the tax and pension systems, in the recognition of professional qualifications, in lending, etc). Undoubtedly, weak labour mobility makes the operation of quantitative adjustments particularly problematic. Thus, if a Eurozone economy is hit by an external shock, labour flows to or from other Eurozone countries are expected to be insufficient to restore equilibrium. Therefore, quantitative adjustment should come from inside the country in question. ${ }^{8}$ Consequently, the criterion of labour mobility concerns not only 'external' mobility (migration) but equally the full range of forms of internal mobility ${ }^{9}$, as the latter emerges as a key mechanism for the amortisation of asymmetric shocks within a monetary union with significant linguistic and other barriers to migration. In the context of the wider neo-liberal shift in the 1980s and 1990s, the proposed policies to encourage this flexibilisation focused predominantly on labour relations - especially on the removal of dismissal restrictions (employment protection legislation), the extension of flexible forms of employment (part-timing, temping, flexible hours, etc.), and the reduction in the generosity of unemployment and other benefits (in order to stimulate active labour force participation and flows out from unemployment and inactivity). However, the set of policies that could stimulate labour mobility cover a much wider range of potential interventions, such as the deregulation of financial and property markets, the reform of education provision at the lower (e.g., establishment of day-long schooling for the children of working parents) and higher levels (e.g., conversion degrees to support career-change), the provision of training (re-skilling) and counselling services to the unemployed, the extension of some types of employee benefits (e.g., maternity leave), and others - not all of which necessarily result in the deregulation of labour relations.

Wage flexibility. Given the various impediments to (internal and external) labour mobility and its social cost, it becomes readily apparent that price adjustments obtain much greater importance. There is a widespread perception that Europe is suffering

\footnotetext{
${ }^{8}$ This substitutability between internal and external labour mobility was already identified in the original work of Mundell (1961).

${ }_{9}$ This includes job mobility (changing employer), occupational mobility (changing occupation), sectoral mobility (changing industrial sector), geographical mobility (in the form either of permanent relocation or of commuting to a different labour market), as well as mobility across job types (e.g., from full-time to part-time, from permanent to temporary, etc).
} 
not only from low labour mobility, but also from low wage flexibility (meaning the flexible adjustment of labour costs to changes in unemployment or inflation). Relatively extensive welfare states (often supplemented by the auxiliary role of the family) and strong labour unions are perhaps the most important factors supporting this perception (Dickens et al, 2006). The welfare state, with the provision of comparatively generous unemployment and other social benefits, effectively reduces the attractiveness of work thus keeping reservation wages artificially high. Similar is the role of the family, particularly in Southern Europe (Ferrera, 1996). On the other hand, strong unions can systematically push for disproportionate to the economic situation wage increases (e.g., above productivity), hindering nominal and real wage adjustments. Although the empirical evidence for such an impact of European institutions on wage flexibility is thin (i.e., it is not too clear how much rigidity these institutions generate in practice ${ }^{10}$ ), it is fair to say that the presence of such institutions may be pivotal in not allowing the further flexibilisation of wages - which may seem critical in the context of EMU, with the loss of control over of monetary policy that it entails for national governments. Instead, there are numerous reasons why one would expect to see an increase in wage rigidity post-EMU, as will be analysed in the next section. Hence, given the low labour mobility in Europe and the lack of strong fiscal transfer mechanisms, the smooth operation of the Eurozone seems to require the enhancement of wage flexibility in its member states. This in turn implies a weakening of trade unions, deregulation and decentralization of wage bargaining, compression (and/or rationalisation) of unemployment benefits and minimum wages and, more generally, comprehensive measures to increase the attractiveness of work and the flexible adjustment of wages to economic conditions.

To sum up, starting from a simple theoretical observation concerning the importance of national adjustment mechanisms within a sub-optimal currency area, we reach a

\footnotetext{
10 The literature tends to agree that taking into account differences in inflation rates between countries, nominal wage rigidity in the European economies is comparable to that of the U.S. economy. With regard to real wage flexibility (i.e., the adjustability of real wages to changes in the unemployment rate), it appears that short-term adjustment of real wages in Europe is indeed limited, while long-term adaptability is equal to, if not higher than, that of the U.S. economy (Layard et al, 1991; Elmeskov and MacFarlan, 1993; Viñals and Jimeno, 1998; OECD, 1999; Turner and Seghezza, 1999; Nickell and Quintini, 2003; Barrell and Dury, 2001; HMT, 2003a).
} 
series of policy proposals (if not political necessities) to increase flexibility across the whole spectrum of industrial relations (cost and numerical flexibility, internal and external flexibility $\left.{ }^{11}\right)$. There are, however, a number of other arguments under which labour market reform in the direction of enhanced flexibility becomes necessary in a monetary union. We discuss these in the following section.

\subsection{Monetary policy and the shift of the 'pivotal triangle' of macro- economic policy}

The establishment of EMU brought about, almost automatically, a fundamental change in economic governance in Europe and, in particular, in the relationship between the three main pillars of macro-economic policy (monetary, fiscal and wagesetting). This has two important implications with respect to the present discussion. On the one hand, the analysis in the previous section and its theoretical basis (OCA) is put into question. This follows from the well-known Lucas Critique, which states that the transition to a new system of governance changes structurally economic relations and behaviour thus rendering irrelevant any predictions derived from the pre-transition phase. This is the essence of the contemporary criticism on the traditional OCA theory, the so-called 'endogenous OCA', which advocates that the creation of EMU will facilitate rapid convergence of the participating economies, thus leading to the synchronization of economic cycles and making the need for fiscal integration and labour market flexibility less important. ${ }^{12}$ On the other hand, the new structure of economic governance in the euro area creates new conditions and challenges that may exacerbate the problems of adjustability and rigidity of the European economy, making new forms of flexibility, and associated measures for the deregulation of labour markets, more imperative. We turn to these changes in what follows.

11 For a discussion of the definition and meaning of the various types of flexibility see Monastiriotis (2006).

${ }^{12}$ See Mongelli (2002) and DeGrawue (2007). 
A basic point of departure for this discussion is that the discretion over the use of monetary policy by national governments entails some build-in inflationary bias (surprise inflation). ${ }^{13}$ National (non-independent) monetary authorities have an incentive to declare a lower inflation target than their actual inflation preference. To the extent that the monetary authorities inspire confidence, this will not lead to inflationary wage settlements as the unions would expect relatively low inflation and thus exhibit wage restraint. Once non-inflationary wage agreements are reached, national authorities are tempted to use (in the short-term) expansionary monetary policy measures to reduce unemployment - even though this creates higher inflation which dilutes real wage growth. Knowing this inherent 'time-inconsistency' problem of national monetary authorities, trade unions will embody in their negotiations this inflationary bias and will tend to seek larger nominal increases, leading to a reduction in nominal and real wage flexibility and an increase in unemployment (with higher inflation). With the transfer of responsibility for monetary policy to a completely independent supranational body (the European Central Bank), which has a clear and deeply institutionalised commitment to price stability, this inflation bias is eliminated and, consequently, inflationary pressures and wage rigidities that stem from it are reduced. Therefore, the creation of EMU leads automatically to the subsiding of the negative role of trade unions, thus making any pressure for the deregulation of collective agreements less significant (Calmfors, 2001).

However, the attainment of low inflation (due to ECB's enhanced credibility and the decline in wage-induced inflationary pressures) has one unintentional yet important consequence: lower inflation implies a convergence in the rates of growth of nominal and real wages (with zero inflation both aggregates grow at the same rate). Given the prevalence of downward rigidity for nominal wages and the political and social costs associated to net reductions in nominal wages (including the constraints discussed above regarding the European labour market institutions, e.g., strong unions, high unemployment, etc ${ }^{14}$ ), the flexibility of real wages also falls. In other words, an ad hoc

\footnotetext{
13 This observation is derived from the models of Kydland and Prescott (1977) and Barro and Gordon (1983) who first raised the issue of the so-called problem of 'time-inconsistency'.

14 It should be noted that a broader set of factors may hamper nominal wage flexibility and/or make it undesirable: among them is the issue of deflation (which leads to structural under-
} 
reduction of labour-cost flexibility takes place. Additionally, the decline in inflation may prompt businesses and unions to agree on wage contracts with longer horizon (to avoid the transaction cost of negotiations), again reducing the short-term adjustment for wages (Calmfors, 2001). ${ }^{15}$ Therefore, even if the set of countries forming a currency union do constitute an ex ante optimum currency area, with (partially) synchronized business cycles and low inflationary pressures, it is possible that these countries will experience an increase of rigidities in their economies and a weakening of their adjustment mechanisms, thus making the currency union ex post sub-optimal.

Moreover, the ability of economic and monetary integration to lead to real convergence and, thus, to economic synchronization is also questioned by the inherent tendency of the ECB, within the framework of EMU, to be itself a cause of asymmetric shocks. As a result of the heterogeneity of wage bargaining systems in the Eurozone and the diversity of the national economies, the ECB is forced to react to a 'weighted average' of inflationary pressures. Unsurprisingly, the ECB's response will be suitable for only a limited number of national economies. For the rest, ECB interest rates will be either inflationary or anti-inflationary, and hence, harmful to stability and growth. ${ }^{16}$ In other words, the ECB itself may be a source of asymmetric shocks even in the absence of purely exogenous shocks (DeGrauwe and Sénégas, 2004). This 'built-in asymmetry' makes the need for deregulation of labour relations even more urgent in order to achieve greater wage flexibility and induce (internal) labour mobility.

Another mechanism that has also stirred much debate in the literature has to do with the ad hoc decentralisation of collective bargaining. ${ }^{17}$ The starting point here is the observation that unions' incentives to seek wage increases above productivity

consumption) and the issues of skills-depreciation and the distortion of incentives for human capital accumulation.

15 See the next section for a different version regarding the duration of wage contracts.

16 Asymmetries may also arise due to national differences in consumer preferences, the behaviour of banks, the size of the export sector (for exports outside the Eurozone), among other reasons (Clements et al, 2001; Clausen and Hayo, 2006).

17 See the original work of Calmfors and Driffill (1988), the formalisation of this relationship in Cukierman and Lippi (1999), and the discussion more recently in Schelkle (2001 and 2005) and Driffill (2006). 
growth (thus creating inflationary pressures and/or unemployment) are non-linearly related to the degree of decentralization of collective bargaining. In perfectly competitive markets, when negotiations are fully decentralized (for example, at the firm level), unions are aware that any wage increase above productivity may push their employer out of business. Hence, the entire cost of a disproportionate wage increase, which will take the form of increased unemployment, will be internalised directly by the union members (who will be fired). ${ }^{18}$ When negotiations take place at the national level (fully centralised), inflationary pressures will be applied throughout the economy and any increase in nominal wages will not be translated into real wage increases. ${ }^{19}$ In both cases a control mechanism is in operation which keeps trade unions' aspirations in check, maintaining a balance between wage increases, productivity gains and inflation and allowing for more wage flexibility in the economy. In contrast, when negotiations are at an intermediate level (for example, at the sectoral level), unions can externalise the cost of their wage demands: wage increases above productivity lead to some layoffs in the sector and put upward pressures on inflation, but if the sector is relatively small the impact on the overall economy is limited. Employees in the sector can enjoy real wage increases while the few layoffs can be absorbed in other sectors of the economy..$^{20}$

With the creation of the ECB and the shift of monetary policy to the supranational level, wage bargaining becomes artificially decentralised, resulting in higher inflationary and unemployment pressures and lower wage flexibility. ${ }^{21}$ Given that the synchronisation of wage negotiations at the supranational level (re-centralisation) is politically impossible (and for other reasons, which are not related to this

\footnotetext{
${ }^{18}$ It should be noted that this reasoning is based on the assumption of perfect competition, which implies that firms have zero profits. If this is not the case, it is possible that the unions can achieve higher wages without redundancies.

${ }^{19}$ If the national monetary authority tries to prevent an acceleration of inflation, by raising its interest rates, the economy will contract and inflationary pressures will take the form of higher unemployment.

20 There is also a significant moral hazard problem: each union has an incentive to behave aggressively, in order not to endanger a potential loss resulting from the aggressive behaviour of other unions. This leads to collective inflationary pressures and hence more wage rigidity in the economy (along with higher inflation and unemployment).

${ }^{21}$ This in turn results in a weakening of the ECB's ability to contain inflationary pressures, through its 'signalling' or 'leadership' on price-setting (Hall and Franzese, 1998; Hancké and Soskice, 2003).
} 
discussion, economically harmful ${ }^{22}$ ), it is evident that the sustainable functioning of EMU requires radical deregulation (decentralisation) of collective bargaining and weakening of union power (coverage / de-recognition). Additionally, however, it requires a substantial reduction in the attractiveness of unemployment benefits (in terms both of their duration and replacement rates), since the ability of unemployment to serve as a disciplining device on the behaviour of unions depends on the size and duration of these benefits (Burda, 1999): if they provide a high degree of coverage of the foregone salary, the cost of unemployment is shifted from the unions and their (displaced) members to the tax-payer, who ends up subsidising the (generous) benefits. Consequently, deregulation and flexibilisation is also on this basis desirable (if not necessary).

In conclusion, it seems that there are a number of issues linking EMU to labour market reform (employment flexibility) besides the lack of economic synchronicity, which is the main issue identified by the OCA theory. These have to do with the change in the functioning of monetary policy (policy commitment / credibility), the shift in the balance between the central pillars of macro-economic policy (pivotal triangle) and the change in the transmission mechanisms of monetary policy. All these factors tend to favour the flexibilisation of labour relations as a means for strengthening the functioning of the Eurozone economy.

\subsection{The political economy of wage restraint - the experience of Maastricht}

In contrast to the arguments considered in the preceding paragraph, it has been argued that with the delegation of monetary policy to a supranational authority and the restrictions placed on fiscal policy (as discussed below), wage changes obtain a central role in ensuring the competitiveness and adaptability of each national economy (Soskice and Iversen, 1998; Hancké and Soskice, 2003). This occurs because the cost of wage increases above productivity burdens exclusively the national

\footnotetext{
22 Amongst them, the main issue concerns the removal of yet another national-level discretionary
} adjustment mechanism that further centralisation will cause. 
economies. Hence, EMU leads to an intrinsic harnessing of wage demands (Lauer, 1999), thus making the need for measures to strengthen labour market flexibility and to weaken the role of unions less relevant. ${ }^{23}$

We can link this observation to the broader discussion concerning the 'embedded wage restraint' in EMU (see, among others, Soskice and Iversen, 1998, Advagic et al, 2005, Donaghey and Teague, 2005 and Hancke and Rhodes, 2005). The main argument here is as follows: whereas during the convergence period (from the Maastricht Treaty to the establishment of EMU) many of the Eurozone countries reverted to so-called 'social pacts' to control inflation and to meet the conditions for participation in EMU, in the post-EMU era we observe a firm adherence to the principle of non-inflationary wage bargains despite the fact that the use of social pacts (formal or informal) has declined substantially. A sensible explanation for this trend is that the logic of wage moderation (and its perceived usefulness for national economic performance) has been internalised by both the national governments and the trade unions in the Eurozone. In other words, the mechanism that allows the necessary adjustment of wages to economic downturns, which is a key aspect of wage flexibility, seems to have become embedded in the functioning of wage bargaining across the Eurozone, albeit to variable degrees. ${ }^{24}$

On the basis of this argument, in contrast to that described above regarding the duration of collective agreements, one would expect not only a continuation of wage restrain but also a further increase in wage flexibility: as unions (and employers) internalise a sense of commitment to price and economic stability, and understand the inability to exercise stabilisation policies at the national level based on monetary

${ }^{23}$ Furthermore, EMU creates additional incentives for wage moderation to achieve competitive devaluations of the real exchange rate (wage dumping) and thus enhance the competitiveness of national economies (Eichengreen, 1998; Traxler, 1999, Martin, 1999, Soltwedel et al, 2000, Hancké and Soskice, 2003). This is largely the experience of Germany in the post-EMU period, which has led to criticisms that this has intensified the deterioration of current account deficits in the less wage-moderate countries of the European south.

${ }^{24}$ We mention above the need to maintain a national economy's competitiveness as one of the reasons why this may happen, while the next section suggests another reason linked to the fiscal constraints imposed by EMU's system of economic governance. Besides these reasons, however, the central argument here is related essentially to the process of socialization / internalisation of wage restraint and not to the various explanations as to why trade unions may rationally decide to moderate their wage demands. 
and fiscal measures, they are likely to promote flexible collective agreements or short-term contracts in order to be able to respond swiftly to unforeseen changes in the economic cycle (Berthold and Fehn, 1998). Therefore, to the extent that the aforementioned internalisation leads unions in the Eurozone to operate with national competitiveness as their main concern, further deregulation and flexibilisation of labour relations becomes more urgent outside than inside EMU (Calmfors, 2001).

Not only that; it can further be argued that the institutionalisation of wage restraint may also be pushing towards a selective regulation of the labour market as, with lower pressures for deregulation, national governments may be inclined to raise labour standards and employment security (regulation of non-traditional forms of employment, maintaining unemployment benefits, expanding retraining programs, etc). This is not only because governments may wish to reward the unions for their contribution to economic stabilisation and maintain their adherence to wage restraint. More importantly, the argument is that with stabilisation achieved, governments can afford to treat employment security, and social policy more generally, as a productive factor (Bertola et al, 2001). ${ }^{25}$ Selective regulation in this sense is linked more to the principle of 'flexicurity' than to the type of flexibilisation endorsed by OCA theory and monetarist theories of integration. ${ }^{26}$

\subsection{Fiscal policy and labour markets}

The implications for labour market reform accruing from the realm of fiscal policy have to do with two main parameters. On the one hand, the objective constraints the EMU imposes on national public finances. On the other hand, the effects on the

\footnotetext{
25 See, in relation to this, the argumentation of the European Commission within the EES (COM, 2007a) and the Lisbon Strategy (COM, 2007b) - see also our discussion in section 3.

26 Nevertheless, a counter-argument can also be made here. The different interpretations concerning the direction that labour market reforms should follow serve to highlight the complexity of the issue and the uncertainty surrounding the policy options. This uncertainty is often interpreted as a policy proposal in itself, taken to demonstrate the need for greater labour market flexibility. The reason for this is relatively simple: in a state of relative uncertainty, precautionary adjustment (labour market reform) is preferable to conservative inaction (Hefeker, 2006 - see also Sibert and Sutherland, 2000; Hughes-Hallet and Viegi, 2003; and HMT, 2003b).
} 
behaviour of the main economic actors (unions, governments, employers) and their incentives structure, resulting from the change in the relationship between fiscal and wage policy. We discuss each one of them in the following paragraphs.

Budget constraints. As is widely discussed in the relevant academic and policy literatures, the model of economic governance of EMU imposes certain limitations on the exercise of national fiscal policy. Specifically, under the Stability and Growth Pact (SGP), a public deficit ceiling in the countries of the Eurozone is set and national governments commit to achieve a mid-term goal of zero deficit (in the course of the economic cycle). ${ }^{27}$ The SGP serves as a deterrent tool for three kinds of risks: first, the diffusion of inflationary pressures, that is, the spill over of inflation from a country that follows expansionary fiscal policy to others which behave with greater restraint; second, the spill over of interest rate hikes, potentially leading also to currency destabilisation, as is currently the situation with the Greek fiscal crisis; and third, the moral hazard problem of fiscal prudence, that is, the situation where as the use of expansionary fiscal policy by one single country is not punished by the monetary authority, each and every country has an incentive to pursue expansionary policies so as to 'pre-empt' the expansionist policies of other countries. According to the logic of the SGP, countries that achieve a zero deficit are able to follow a (controlled) expansionary policy in times of recession or in response to exogenous shocks (symmetric or not), even beyond the operation of so-called 'automatic stabilisers'. For countries with structural deficits, however, the possibility to bring the government budget 'close to balance or in surplus' is extremely limited. For them, the SGP operates as a very powerful budget constraint pushing for the containment of public expenditures and the reduction of their structural (inelastic) elements. In the labour market, these are translated into policy interventions aiming primarily at containing wage increases (in both the public and private sectors) and reducing the generosity (size, availability and duration) of unemployment benefits (Calmfors, 2001; Farina and Tamborini, 2004; Enderlein, 2006). But they also expand to the deregulation of

\footnotetext{
${ }^{27}$ It should be noted that these criteria hold under certain conditions. Also, the application of the 'dissuasive arm' of the SGP (the 'Excessive Deficit Procedure') is subject, at least to some degree, to political pressures and dynamics. Such issues fall outside the scope of this paper and are thus not discussed here in any detail.
} 
employment protection more generally. ${ }^{28}$ In addition, national authorities are forced to implement active labour market policies to increase the employability of the workforce, enhance its mobility and adaptability, and to reduce benefit dependence. Thus, restrictions on fiscal policy, which stem directly or indirectly from the adoption of the single currency, lead to a number of changes in the labour market, which, paradoxically, extend to areas much wider than those resulting from the analysis of the OCA theory.

Political exchange. It is clear from the above that, except possibly in special cases, national fiscal authorities are unable to meet, even if they wish (e.g. for politicalideological reasons or for short-term electoral considerations), the demands from trade unions for generous wage increases in the public sector (and, by extension, in the private sector). This 'external empowerment' leads to the neutralisation of one of the main mechanisms that make fiscal policy inflationary, namely the process of political exchange between governments and unions (IMF, 2004; Duval and Elmeskov, 2006; Acocella et al, 2007)..${ }^{29}$ Labour unions are aware that the budget constraints on the public finances are real and insurmountable. They thus ease their wage demands, even if they contest the budgetary constraints, because they realise that no inflationary pressures will arise from the wage demands of other unions. Hence, the weakening of political exchange also solves the moral hazard problem of union behaviour, in which each union is led to seek extra-normal wage increases because it expects other unions to do the same - shifting the costs of their wage increase to the unions that follow a moderate wage bargain (and/or to the nonunionised employees). As a consequence of this 'external empowerment' and the

\footnotetext{
28 This takes place as follows. With the need to reduce the inelastic components of the state budget, national authorities are pushed to a more extensive use of non-traditional forms of employment (contract work, fixed-term contracts, temporary employment, part-timing, etc.) and more flexible forms of labour use and remuneration (annualisation of working hours, shiftworking, non-paid overtime, performance-related pay, etc). This results to the institutionalisation of such employment arrangements, leading to their diffusion across the economy.

29 The political exchange hypothesis is based on the assumption that, in the short-term, governments have an interest to succumb to pressures to raise wages above productivity in return for political support from the unions or to obtain wider support from their electoral constituencies (under the logic of collective inaction).
} 
wage discipline that it generates, pressures for labour market reform are eased and the pursuit of more flexibility in the labour market becomes less warranted.

Therefore, we see that, as in the case of monetary policy (sections 2.2 and 2.3), the effects of monetary integration on the labour market in the case of fiscal policy are also ambiguous. Some arguments seem to favour significant and sometimes radical changes towards more flexibility in the labour market. Others, seem to suggest that the common currency and the mechanisms of economic governance that have been put in place in EMU work towards the easing of pressures for labour market reform, by resolving the constraints that institutional rigidities at the national level apply on the adjustment mechanisms of the participating economies. In effect, this view maintains that economic governance under EMU manages to resolve tensions and constraints that can not be resolved unilaterally at the national level. This leads us to two further observations, with which we conclude this section. First, the creation of EMU can be seen either as a constraint or as a catalyst (facilitator) for the reform of industrial relations in Europe. Although under the pressures stemming from both exogenous (e.g., globalisation, technological progress, population aging) and endogenous processes (the institutional and behavioural changes induced by EMU) reforms may be seen as necessary, the direction of these reforms -and the qualitative, quantitative and redistributive changes involved- is an issue that remains largely open and unresolved by economic theory. The final policy outcome, therefore, can only be determined politically. Second, the pressures for labour market reform in EMU stem from two qualitatively different stipulations: on the one hand, the need for stability and resilience to external shocks, under a system of fixed exchange rates and an insulated centralised monetary policy; on the other hand, the need for an institutional framework of industrial relations that will enhance the quality and competitiveness of the European economy. It is this 'dual mandate' of two largely competing stipulations that the EU seeks to manage through its employment policy and the net of institutional arrangements for policy design, intervention and coordination that it has developed. We turn to this institutional framework next. 


\section{Transnational regulation and cooperation in the field of employment in the EU}

\subsection{The framework for employment policies in the EU}

Despite the chronic problems of low flexibility and mobility combined with high and structural unemployment (but not surprisingly due to the political importance that governments assign to the control of employment policies), the EU has failed to develop a comprehensive employment policy either at the supra-national or the transnational level. As a result, the significant diversity characterising the organisation of national labour markets and the corresponding models of industrial relations in Europe has been maintained. Nevertheless, elements of supra-national and transnational regulation exist. In fact, since the inception of EMU, the EU has developed a rather complex institutional framework for employment policy and policy coordination. This framework is organised along three pillars. The first pillar concerns the EU Directives on employment, which thus consists one of the historic EU policies, originating from the founding Treaty of Rome. The second and third pillars, Euro-corporatism and the EES, respectively, were developed in the 1990s, marking a new era in the governance of employment policies in Europe. The development of these two pillars is undoubtedly attributable, at least in part, to the need for transnational regulation of labour markets and harmonisation of national employment policies under the pressures arising from the adoption of the single currency, as discussed above.

European directives. This has been the exclusive form of European employment policy since the establishment of the EU until the Treaty of Maastricht in 1992. The existence of EU directives in the field of employment is based on the premise that the disparity between Member States in the field of social policy is widely a distortion of free competition within the European market (Geyer, 2000; Begg, 2002). Generally, the EU directives are the product of European Commission's activism and intergovernmental politics at the Council. But once agreed upon, they are legally 
binding for all member states and their implementation is supported by the decisions of the European Court of Justice (ECJ) and national courts..$^{30}$ The directives reflect the dual objective of the EU, on the one hand to support the functioning of the single market by removing impediments to the free movement of labour and/or access to welfare provisions (negative integration) and, on the other, to spur an upward harmonisation of employment regulations (positive integration) in order to avoid unfair competition (social dumping) between member states - which also acts to improve working conditions and living standards (Goeyer, 2002). ${ }^{31}$ However, they do not seek to accomplish complete harmonisation: the directives respect the heterogeneity of industrial relations and employment law of the Member States and therefore their aim is to achieve partial harmonisation (Kenner, 2003). The first pillar was reinforced in successive treaty reforms ${ }^{32}$ and has shown significant activism: since the Treaty of Rome, the Council has issued about 8000 decisions and the Commission has issued over 80 directives covering the three broad areas of health and safety at work, general conditions (redundancies, organization working hours, parental leave, etc.) and gender equality (Falkner et al, 2005). ${ }^{33}$ The chart below reflects the breakdown of the directives in three categories for the period 1975-2002.

\footnotetext{
30 Their legal / coercive nature, however, is limited by the slow and limited transposition into national legislation in the member states (Falkner et al, 2005).

31 See Leibfried and Pierson (2000) and Leibfried (2005) for a discussion of how this interferes with member states' social policy thus constituting national welfare states 'semi-sovereign'.

32 In the Single European Act (1987), Quality Majority Voting (QMV) was introduced in the Council in the area of harmonisation of health \& safety standards, thus overcoming the veto power of member states under unanimity. In the Treaty of Maastricht (1992) the Social Protocol was introduced (but not approved by the UK) and provided for QMV for additional areas such as working conditions and workers' consultation. In the Treaty of Amsterdam (1997) these were strengthened with the signing of the social protocol by Britain, the enhancement of the role of the European Parliament and the extension of QMV to almost all areas of the first pillar. For a detailed analysis of the development of this pillar see Goeyer (2002) and Rhodes (2005).

33 See the work of Bercusson (1994 and 1995), Blanpain and Engels (1995) and Shaw (2000) with regard to working conditions; James (1993), Eichener (1997) and Vos (1999) regarding health and safety; and Hoskyns (1996) and Mazey (1998) regarding gender equality.
} 
Figure 1: EU Directives on employment, 1975-2002

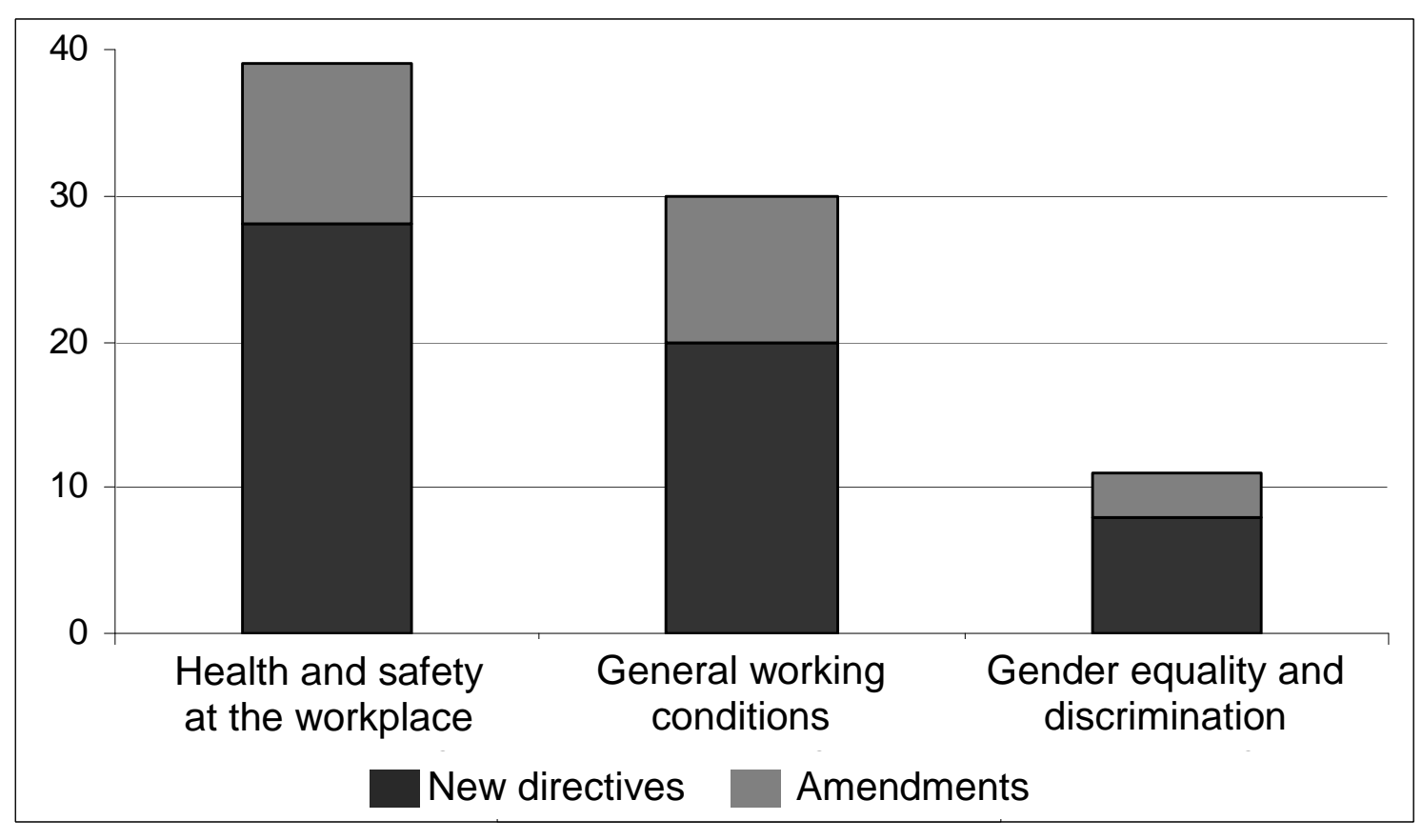

Source: Adapted from Falker et al (2005).

Euro-corporatism. The second pillar of the European employment policy was introduced in the Maastricht Treaty as a response to monetary integration. The directives resulting from this pillar do not originate from the European Commission but from voluntary agreements among the European social partners, which are then approved by the Council; in other words the directives of the second pillar are the result of collective agreements between social partners and Member States (hence the term 'Euro-corporatism'). This pillar includes two types of instruments: framework laws, which are binding but flexible (in that they offer a list of options from which Member States are free to choose what to implement), and recommendations, which are rigid (firm rules) but non-binding. However, this pillar has not been particularly productive and only three directives have been issued so far (Chiattelli, 2008) - with their application being mandatory only in the case of large multinational companies 
(Barnard and Deakin, 2000). ${ }^{34}$ Thus, until now, this pillar has had limited influence on the labour market policy of the Member States.

The European Employment Strategy. In 1993, the European Commission published its 'White Paper on Growth, Competitiveness and Employment', which intended to strengthen the EU's competitiveness as well as its social dimension, largely as a counterweight to EMU, seeking to ensure a balance between competitiveness and social solidarity (Goetschy, 1999, Arnold and Cameron 2001). In essence, it sought a coupling between non-inflationary policies, which were required to meet the Maastricht criteria, and employment-promoting policies through a combination of supply-side and Keynesian policy proposals. ${ }^{35}$ Despite sometimes fierce opposition by member states, which obstructed or delayed its implementation (Goetschy 1999, Trubek and Mosher 2003, Regent 2003), the White Paper was an important catalyst for bringing the issue of employment policy at the centre of the European agenda (de la Porte 2002). A combination of pro-European and social democratic actors in the Commission, the Council and the European Parliament, along with the strong support of Sweden (which joined the EU in 1995) and UK's relatively pro-European stance under New Labour, achieved the formal adoption of the European Employment Strategy (EES) in the Treaty of Amsterdam (1997). The EES constitutes the third, most ambitious and innovative pillar of European policy in this field as it involves a radical shift from binding regulations and instructions (hard law) of the previous pillars to flexible or non-binding targets (soft law), and a redefinition of policy objectives from (passive) employment protection to (active) employment promotion and its qualitative upgrading (Rhodes, 2005). ${ }^{36}$ Initially, the EES comprised 19 Employment Guidelines, which were organised into four main pillars:

34 These were on parental leave (1996), part-time employment (1997) and fixed-term contracts (1999).

35 The White Paper's five main pillars were the following: (i) investment in vocational training, (ii) increasing employment through intensive development, (iii) reducing non-wage labour costs, (iv) increasing active labour market policies and (v) combating youth and long-term unemployment.

36 The EES is considered as model for the 'Open Method of Coordination' (OMC), which is the main method to promote the Lisbon Strategy. The Commission, in cooperation with the Council, defines policy objectives, but their implementation lies at the national level - relying on peer pressure and the exchange of best practices but without legal coercion (Hodson and Maher, 2001; Regent, 2003). Hence, the OMC aims at convergence of national policies but not full harmonization. 
employability (reduction of unemployment and implementation of re-activation policies), entrepreneurship (creation of new businesses, tax incentives), adaptability (modernisation of the organization of work, lifelong learning, extension of employment regulations to non-typical forms of employment, etc.), and equal opportunities (gender equality, work-life balance, reintegration of disadvantaged groups). ${ }^{37}$ Additionally, specific quantitative targets were set on employment levels (total labour force participation rate of $70 \%$ by 2010 - $60 \%$ for women and $50 \%$ for older workers). In 2003, three broad and interrelated objectives (full employment; quality and productivity at work; and social cohesion and integration), replaced the pillar system, while the Employment Guidelines were replaced by 10 'Integrated Guidelines' (which include both EES and BEPG guidelines - these were reduced to 8 after the 2005 reform).

Based on some of its objectives, it could be argued that the EES can be seen as a mechanism that promotes neo-liberal economic policies based on supply side economics - for example because of its emphasis on activation and labour market adaptability (Begg, 2002). ${ }^{38}$ It could be further argued that its soft-law nature and non-coercive character ${ }^{39}$ also facilitates the deregulation of labour markets and employment relations, as it allows instances of negative integration (a 'race to the bottom') without being able to enforce elements of positive integration (a 'race to the top'). According to this view, although presented in part as a counterweight to EMU, the EES appears to be perfectly adapted to the requirements of monetary integration, especially those concerning fiscal prudence, as it excludes the use of expansionary measures to combat unemployment and places the criterion of adaptability over and

\footnotetext{
37 These four pillars try to tackle the four fundamental problems of the European labour markets: the lack of skills (skills gap), the lack of demand (jobs gap), the lack of adaptability (adjustment gap), and inequalities (gender gap) (Larsson, 1998).

38 Moreover, one of its basic social elements, gender equality, which was one of the four pillars during the first period, was demoted into one of the 10 priorities after 2003, and then disappeared in the 2005 reform (see Fagan et al, 2006). Likewise, the EES did not include, after the Member States' fierce opposition to one the Keynesian-type objectives of the White paper, the increase of public and private investment to enhance work skills and entrepreneurship (Foden and Magnusson, 2003).

39 With the 2003 and 2005 revisions, the EES became even less coercive. One important reason for this was the merging of the Employment Guidelines with the Broad Economic Policy Guidelines, which allows Member States to give fewer and more abstract answers/references to labour matters and employment policies in their National Reform Programs (NRPs). An extreme example of this is Italy, whose NRP for 2005 makes no reference to the issue of employment.
} 
above that of quality in work (Chalmers and Lodge 2003; Talani 2004; Raveaud 2007). It should not be underestimated, however, that the EES offers a policy recipe that adds a social and qualitative dimension to the pursuit of flexibility and adaptability which, as we discussed earlier, may seem to be induced, according to some interpretations, by the establishment of EMU. In this respect, the EES enables the interpretation of the two objectives of flexibility and competitiveness (through quality and productivity at work) as complementary.

According to Allan Larsson, former Director General for Employment (DG V) and one of the leading advocates of this interpretation, the problem of unemployment in Europe requires joint action at two levels: on the one hand, towards price and economic stability, achieved through the establishment of EMU; on the other hand, towards the formulation of common policies on employment which will increase the employability of the workforce and the quality of jobs in Europe (Larsson, 1998). The EES covers this second level and, despite its 'softness', it has put significant and targeted pressures ${ }^{40}$ on the EU Member States to coordinate their labour market reforms and enhance the adaptability and competitiveness of their labour markets.

\subsection{The European experience of reforms}

It should become obvious from the preceding discussion that the pressures exerted on labour markets and, by implication, on labour market reform in the countries of the Eurozone over the past fifteen years are manifold. On the one hand there is the catalytic impact of globalisation, which raises both economic interdependence and policy uncertainty. On the other hand, there is a series of pressures and constraints emanating from EMU (which, incidentally, was to an extent a response to globalisation), some of which have a more grounded economic justification (e.g., OCA effects) while others stem mainly from a problematique over the exercise of macro-economic policy inside a monetary union. Besides these pressures and

40 In the 2000-2004 period alone, the Council (after recommendation by the Commission) adopted 280 country specific recommendations for the implementation of the EES guidelines, representing an average of 4.5 recommendations per country per year. 
constraints, and partly in response to them, the EU has developed an articulate set of policy proposals, recommendations and binding directives, aimed at influencing national employment policies and stimulating the institutional reform of the European labour market. Finally, one should not underestimate the internal pressures exerted on the labour markets of the Eurozone countries - in both their economic and political dimensions (for example, persistent unemployment or inequality, generating pressures for reform).

Given that the EU has neither the ability nor the desire to harmonize fully the institutional framework of Eurozone's labour markets, the diversity of these pressures inevitably leads to a complex and diverse picture of labour market reform in Europe. It is generally accepted that, at least for the period from the late 1990s onwards, EU countries in and outside of the Eurozone, have followed neither homogeneous nor unidirectional employment policy reforms (aiming towards deregulation). Instead, Europe is characterised by a multitude of 'welfare models' and modes of regulation - from the socially generous and effective, in terms of employment levels, 'Nordic model', to the more competitive, socially less generous, but probably equally effective, 'Anglo-Saxon model'. In between, there are less effective but more protectionist models ('Continental' model) and others with economic and labour market dualism (protection for the 'insiders' - flexibility for the 'outsiders') and even lower efficiency ('Mediterranean' model) (Esping-Andersen, 1990; Ferrera, 1996; Crouch and Streeck, 1997; Regini and Esping-Andersen, 2000; Auer, 2002; Amable, 2003; Hancke et al, 2007).

But even within each model, the policies pursued deviate from the ideal categorisation and are not unidirectional. For example, Britain, which for many possesses the most flexible labour market in Europe, has introduced over the last decade measures that seem to enhance labour market rigidity, such as the national minimum wage and the extension of parental leave, as well as measures in the direction of more flexibility, by promoting flexible working time arrangements, reducing the generosity of unemployment benefits, and further weakening the role 
Beyond the crisis

of trade unions (HMT, 2003a; Monastiriotis, 2005 and 2007; Tinsley and Monastiriotis, 2007).

Therefore, it is very difficult to ascribe policies pursued in the labour market to specific stimuli, such as EMU or the EES. Likewise, it is equally difficult to summarise in a few paragraphs the wealth of institutional frameworks and the rich experience of labour market reforms that exist in Europe. In the remainder of this section we provide a brief review of this experience drawing on the OECD's monitoring and evaluation system of labour market reforms relating to the period 1994-2004. ${ }^{41}$

Figure 2. Index of labour market reform intensity, 1994-2004

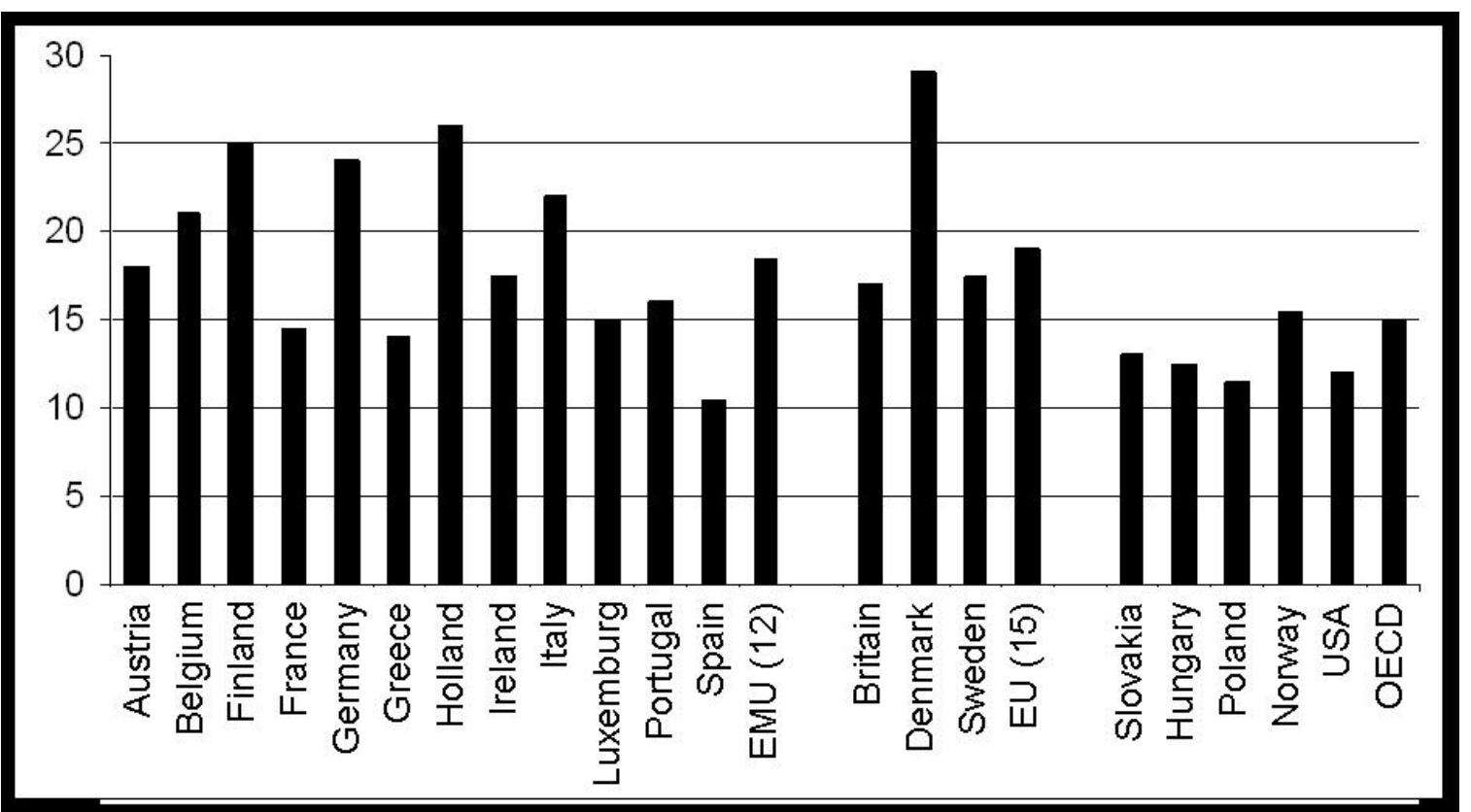

Source: Adopted from Duval and Elmeskov (2006).

As depicted in Figure 2, for the period 1994-2004 Eurozone countries implemented more labour market reforms than other OECD countries. Nevertheless, the index of

41 The OECD assesses its member states' reforms on the basis of 44 criteria grouped into seven broad areas. For more information on the calculation of its benchmarks, see the work of the $\operatorname{OECD}(1994,1996,1999$ and 2006) and the study by Duval and Elmeskov (2006). 
reforms in the countries outside EMU (Britain, Denmark, Sweden) is also high ${ }^{42}$, while the differences within the Eurozone appear to be greater than those between the Eurozone and the OECD, ranging between $10-15 \%$ in countries such as Spain, Greece, France and Portugal, and over $25 \%$ in countries such as Finland, the Netherlands and Germany. Thus, while on a first reading it could be argued that EMU is associated with greater intensity of labour market reforms (since countries like Norway and the U.S. appear to lag significantly behind in the OECD classification), in reality we see very significant differences within the Eurozone, which suggest that labour market reforms in Europe cannot be solely explained on the basis of EMU. Nonetheless, other possible explanations also do not appear particularly strong. For example, reforms are not more pronounced in countries with higher unemployment or greater protectionism, nor are they less pronounced in countries with overall higher levels of flexibility - as one would expect on the basis of the 'initial conditions' and 'reform necessity' hypotheses (Duval and Elmeskov, 2006). If anything, in the EMU an inverse relationship between reform intensity and 'initial conditions' is observed, as the EMU countries that implemented the most extensive and radical reforms were those that had the lowest unemployment and highest employment rates. ${ }^{43}$

Another factor to be considered is the timing of reforms. As above, the immediate conclusion stemming from our discussion in section 2 is that changes in the Eurozone countries should be more extensive in the post-EMU era. As shown in Figure 3, the empirical evidence does not confirm this. The Eurozone countries have high intensity of reforms during the period 1994-1998, which is entirely in line with that of the three member states of EU-15 that remain outside EMU and greater than that of other OECD countries during the same period. But in the post-EMU period (1999-2004), reforms in the Eurozone appeared to subside compared to the three

\footnotetext{
42 Denmark is a double exception: on the one hand, it implemented a very intense reform program, combining policies of increasing flexibility with policies strengthening job security (Bredgaard et al, 2005); on the other hand, while not participating in EMU, it has linked its currency to the Euro (through ERM-II) and therefore can not be regarded as having fully independent monetary policy.

${ }^{43}$ Another 'initial condition' in the literature is the size of the country. Neither this hypothesis seems to be vindicated by the OECD data.
} 
countries outside EMU and to converge, instead, to those of other OECD countries. ${ }^{44}$ It is particularly interesting that while the intensity of reform within EMU declines even in absolute terms, for the three countries outside EMU there is an absolute increase in the intensity of reform.

Is it therefore reasonable to conclude that EMU appears not to reinforce the reform efforts in the Eurozone countries, or even to moderate them? First, it should be noted that at least some of the pressures for labour market flexibilisation stemming from the establishment of EMU (for example those relating to the OCA theory) existed also before the adoption of the single currency. Therefore, to some degree at least, the relatively high intensity of reforms witnessed in the Eurozone countries during the 1994-1998 period may be related to the fact that these countries anticipated the impacts from EMU and thus implemented relevant policies in advance of their accession to EMU. To the extent that this happened, it is plausible that the Eurozone countries suffer in the post-EMU era some form of 'reform fatigue' (Hughes-Hallet and Lewis, 2004). This may be especially true if the effort to meet the Maastricht criteria led to a weakening of their 'political capital' which is necessary for implementing reforms (Duval and Elmeskov, 2006). ${ }^{45}$ Moreover, EMU entry and the comparatively successful path of the new currency may have weakened (until the eruption of the financial crisis in September 2008) the pressures for reform, as they made the prospect of an economic crisis for any country participating in the Eurozone more distant, thus giving the sense that the need for reforms is not that urgent. ${ }^{46}$ It is thus difficult, also on the basis of these arguments, to reach a definite conclusion on the role of EMU in promoting labour market reforms.

\footnotetext{
44 This observation contradicts the results of Bertola and Boeri (2002) who argue that the adoption of the Euro led to an acceleration of reforms in the period 1997-2002 compared with 1986-1996. The fact that the use of different reference periods leads to qualitatively different conclusions illustrates how cautious we should be when analysing trends such as those depicted in Figures 2 and 3.

45 For a detailed discussion of the factors that hinder or delay labour market reforms in the national context see Leiner-Killinger et al (2007).

46 The argument is that reforms are carried out more easily and more intensively in times of crisis ('back against the wall' logic - see IMF, 2004; Alesina et al, 2006; and Hoj et al, 2006).
} 
Figure 3. Reform intensity index by period and geographic region

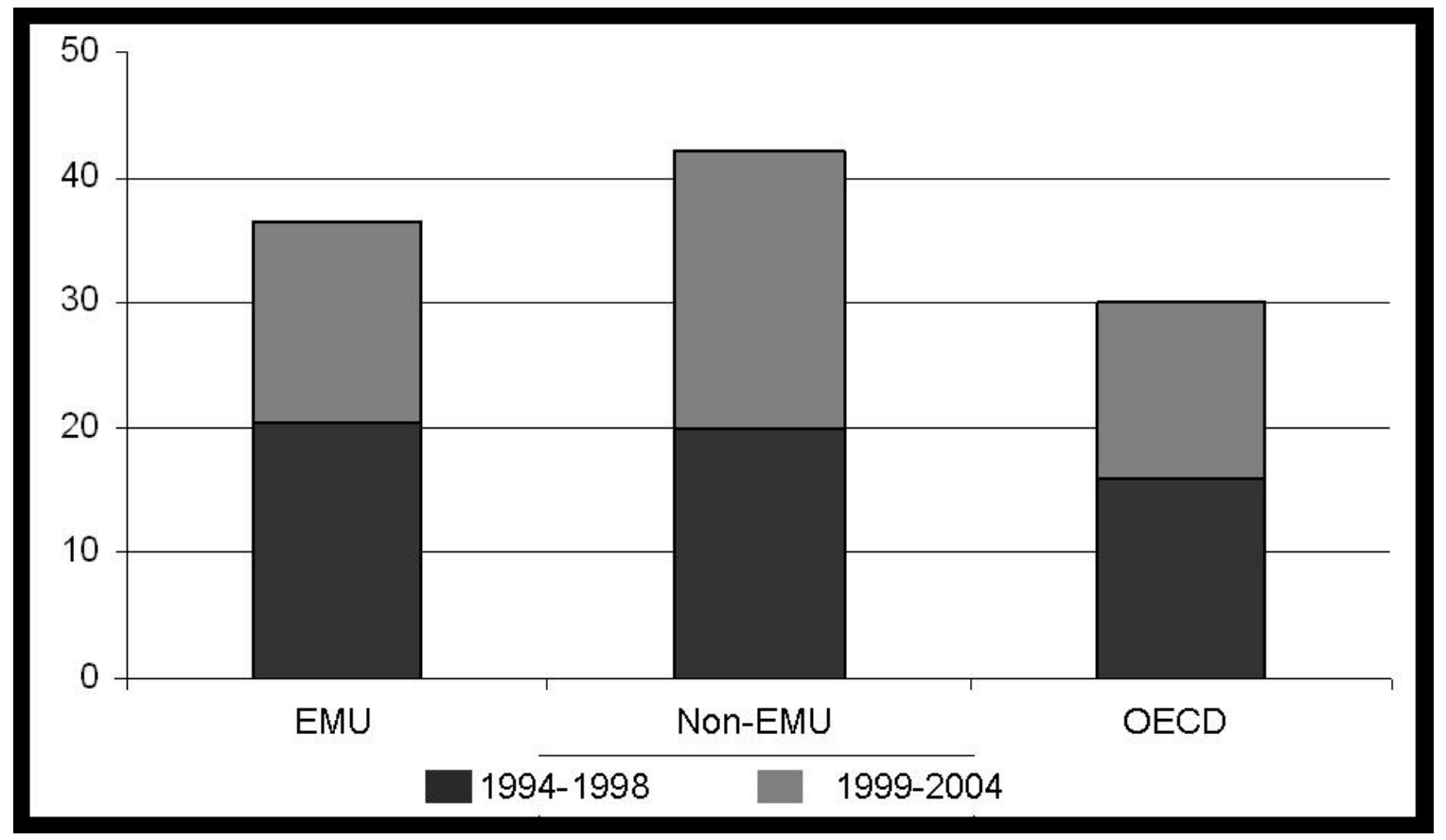

Source: Adapted from Duval and Elmeskov (2006).

An additional dimension in the discussion about labour market reforms in EMU has to do with the degree of uniformity (width) of the reforms and the intensity (depth) of the changes brought about in each country. ${ }^{47}$ OECD data show that most of the EMU countries have implemented more extensive and deeper reforms than the OECD average (Duval and Elmeskov, 2006), although a general observation is that in most cases this does not reflect a general trend towards reforms in the entire spectrum of policy areas (width), with the exception of countries such as Denmark ${ }^{48}$, Finland and the Netherlands. In any case, there seem to be no major systemic differences between EMU countries and the rest with regard to the policy areas where reforms are implemented. In particular, in the areas of active labour market policies, non-wage labour costs (labour tax wedge) and flexi-time, the EMU countries have made much greater progress than non-EU countries but not greater than that of

${ }^{47}$ For an analysis and explanation of how these are calculated see Duval and Elmeskov (2006, p.23).

${ }^{48}$ As noted above, although formally outside EMU, the fact that its currency is linked to the Euro allows us to perceive Denmark more as an insider than an outsider to EMU. 
the EU countries that are outside EMU. In contrast, reforms in the areas of employment protection legislation (EPL) and unemployed benefits have been more modest. Again, we reach the same conclusion: the intensity and direction of reforms varies significantly thus not allowing the safe identification of common trends.

In summary, then, we can conclude the following. First, it is obvious that EMU triggers a multitude of challenges and pressures for reforming the industrial relations and the institutional framework of the European labour markets. The experience of the Eurozone countries, however, shows that the reforms that have taken place are neither uni-directional (towards flexibility) nor uniform, since there is considerable variation both among countries and across policy areas. Instead, the main trend that emerges is that of an 'exploratory activism', where all countries (in and outside EMU) are looking for modern solutions to the real problems of modern capitalism and to the pressures emanating from globalisation (which, for the Eurozone countries, include pressures arising from the adoption of the single currency and of a common monetary policy). It is in this process of active exploration that the revised (after the Treaty of Amsterdam) institutional framework of the European employment policy seeks to contribute, having triggered already a series of conceptual and administrative-institutional changes (Zeitlin et al, 2005; Heidenreich and Zeitlin, 2009). Even though these changes result partially to a reorientation of policy towards more neo-liberal policy objectives (from tackling unemployment to generating employment; from passive income support to activation of the unemployed; and from the curative to the preventive treatment of unemployment), they nonetheless include some elements that promote a stronger social dimension in the design of employment policy and of social policy more generally (e.g., the promotion of gender equality - see Rubery, 2002). This has been facilitated by a number of developments at the EU level since the 1990s, including the extension of QMV in the Council, the strengthening of the role of the European Parliament ${ }^{49}$ (first pillar) and of the social partners (second pillar), the requirement

49 In January 2009 the European Parliament rejected the Council's proposal for the further flexibilisation of working time (annualisation of working hours and extension of the opt-out rights of national governments). The subsequent negotiations failed to break an agreement between the Parliament and the Council. Although this may be seen by some as negative progress 
for greater coordination between member states and greater consistency between policy areas (third pillar), and more generally the introduction of a longer-term perspective in the design and conduct of employment policy. This has resulted in the gradual emergence of the flexicurity model, which has been incorporated since 2005 in the EES and the Lisbon Strategy, as the basic strategy and policy proposal of Europe (COM, 2007a and 2007b). In this regard, the European employment policy (and especially the ESS) leaves an indelible impact on labour market reforms in the post-EMU era, as it encourages the active exploration for economically optimal and socially desirable forms and mixes of flexibility (Larsson, 1998), it promotes the coupling of social protection and economic efficiency (Bertola et al, 2001), and it allows the Eurozone to achieve, on the one hand, a harmony between employment and other macro-economic policies, and on the other hand, a differentiated harmonisation of national employment policies (Begg, 2002).

\section{EMU enlargement and the challenges ahead}

The Central and Eastern European countries (CEECs) that joined the EU in the 2004 and 2007 enlargements have a number of structural characteristics that are radically different to the ones of the economies of EU-15. First, their economic cycles are not fully synchronised with those of the Eurozone countries. Second, their economies in general, and their financial bases in particular, are not sufficiently developed to enable them to function adequately towards shock absorption (symmetric or not) inside a monetary union. ${ }^{50}$ Third, and more importantly for our discussion here, it is quite doubtful whether the labour markets of these countries have the necessary degree of flexibility (and the necessary mix of flexibility and security) to allow their

with respect to the ability of the EU to regulate, in our opinion, it demonstrates the possibilities offered by the new institutional framework of the European employment policy for the establishment of a more democratic and socially sensitive employment policy design.

50 Of course, this characteristic makes them particularly vulnerable in periods of crisis also outside EMU, as the recent experience of Hungary and the Baltic countries has shown. 
smooth accession into a currency union. ${ }^{51}$ This asymmetry between the Eurozone and the CEECs raises significant issues of adaptation and creates additional pressures on the labour markets both in the CEECs and in the existing Member States of EMU.

\subsection{Pressures on the labour markets of the acceding States}

Unsurprisingly, the pressures for CEECs will be to a large extent similar to those that were put on the current members during their efforts to meet the Maastricht criteria and achieve EMU membership. That is, pressures for increasing wage flexibility and deregulating their industrial relations in order to encourage labour mobility. However, some important differences exist. The transition process has enhanced phenomena of corruption and economic informality in these countries, which create a significant 'flexibility on the margin' (Boeri, 2004) in their labour markets. The latter paradoxically allows both quantitative and, especially, cost adjustments, regardless of the degree of regulation in the formal economy. Therefore, it should be expected that the pressures for further labour market deregulation in the CEECs are limited because, albeit for the wrong reasons, their labour markets have adjustment mechanisms in place that can absorb the impact of exogenous shocks. Furthermore, these countries have very intensive trade and capital flows with the Eurozone, in some cases more than some of the Eurozone countries themselves (for example, Ireland and Finland). Consequently, if the Eurozone were affected by an exogenous shock, this would diffuse relatively swiftly in these countries: this is exactly what happened to countries such as Hungary and Latvia in the current economic crisis. By implication the two sets of economies become more synchronised thus making the ECB response to the shock largely compatible to the CEECs.

\footnotetext{
${ }^{51}$ However, these countries' decision to join the EMU is essentially political. Furthermore, it should be noted that staying within the EU but outside EMU involves major problems and instability for these economies, making their quick entry into the EMU probably more warranted (Buiter, 2004).
} 
Nevertheless, one should not neglect that the CEECs are still in a process of reconstruction and transformation, which involves significant shifts in production and employment, e.g. from agricultural production and some traditional industries to the service and high-tech sectors. It also includes significant changes in the geographical distribution of employment, as well as significant investments in new skills and qualifications, largely activated by the inflow of foreign direct investment (FDI). As the CEECs progressively converge to the European average, the continuation of FDI flows depends increasingly on production costs (including unit labour cost), as the CEE economies lag substantially in terms of product differentiation and technological expertise. Accordingly, these countries need to strengthen the sectoral and geographical mobility of their workforce, to increase employment transitions (flows to and from full and part-time employment and unemployment), to increase the adaptability of their wages, and to curb wage increases across the economy (formal and informal). Their entry into EMU will make that need even more apparent.

This is a quite different strategy from the one the CEECs adopted in the last fifteen years. During their transition, these countries adopted rather generous income and unemployment support measures (unemployment benefits, disability benefits, etc). At the same time, they followed quite aggressive policies on wage restraint (incomes policies and social pacts) and employment deregulation (Burda, 1988; Boeri and Terrell, 2002; Boeri, 2004). This policy mix aimed at facilitating economic stabilisation and restructuring while legitimising politically the transition reforms and dealing with their distributional implications (and especially with the acute problems of poverty triggered with the fall of communism). It thus provided for important safety nets outside the labour market, which had a clear social and redistributive character. The new pressures for policy interventions to increase labour mobility and tackle long-term unemployment and inactivity (e.g., through activation policies and reskilling) are largely in conflict with this 'safety net' function, thus threatening to undermine the sustainability and legitimacy of the employment relations system in these countries. Therefore, the pressure is there to reconfigure these systems in a way that addresses simultaneously the need for preserving social solidarity / equity and 
enhancing efficiency / adjustability. This in turn requires significant improvements in planning (institutional design, cost-effectiveness) and more effective targeting (see Barr, 1994 and 2005).

Thus, whereas the CEECs do not appear to be in a very precarious position regarding the consequences of EMU membership on their labour markets (at least in relation to the situation faced by countries in Southern Europe on their way to EMU), their process of transition and transformation that is still taking place and the subsequent tensions that emerge for policy indicate the need for greater adaptability and flexibility, but also for more targeted regulation. While this is not a direct result of EMU, the latter will largely accentuate the need for greater flexibility, as it will strengthen the transformation mechanisms (reallocation of jobs, industrial restructuring, etc.).

It should also be stressed that the prolonged stay inside the EU but outside EMU creates in itself pressures on the CEE labour markets. First, remaining outside EMU can be the source of increased turbulence and instability to the financial systems of these countries (Buiter, 2004) - as has been recently become evident in the cases of Hungary and the Baltic countries, or even Denmark. Secondly, the simultaneous pursuit of real and nominal convergence (i.e., containment of inflation and external debt and maintenance of a stable exchange rate against the Euro) is likely to cause inflationary pressures and economic instability (due to the 'Balassa-Samuelson effect'). As a result, a number of changes in the labour market, such as increased wage flexibility (in the non-tradable sector) and labour mobility (mainly across sectors of the economy) are necessary. Such changes are largely in the same spirit to those induced by EMU entry as predicted by OCA theory but in this case they operate in the absence of accession to EMU.

For the CEECs, therefore, the pressures for labour market reform are almost independent of their entry into EMU. They stem from the ongoing restructuring of these economies and the imbalance caused by EU membership and the subsequent intensification of economic integration with the Eurozone. The major challenge facing ahead is maintaining and strengthening the available forms of flexibility, 
while eradicating the informal economy and reforming social benefits in ways that maintain their philosophy but improve their effectiveness.

\subsection{Adjustment costs to existing EMU members}

On a first reading, the pressures exerted on current EMU member-states due to a prospective enlargement of the Eurozone are rather limited. EMU is already rather heterogeneous and for the most part its CEE enlargement adds very little to this heterogeneity and shifts the centre of gravity of ECB decision-making only marginally. Given that, as we argued in section 2, the pressures on the Eurozone labour markets emanating from the asymmetry of monetary policy are inconclusive, it is probably reasonable to expect that the labour market impact of the enlargement of EMU will be in this respect rather small. However, more significant pressures can arise from the asymmetry, not of monetary policy, but of the labour markets of the old and new member states (Boeri and Garibaldi, 2006). This is because the 'flexibility at the margin' that characterises many CEECs can create pressures for further flexibilisation of industrial relations in existing members-states, especially in terms of cost flexibility (Hughes-Hallett and Jensen, 2003), under the enhanced capital mobility and price transparency facilitated by the common currency. In other words, monetary integration of CEECs can lead to a 'systems competition', activated either through migration and firm relocation (the 'exit' strategy) or mainly through a 'wage dumping' mechanism, that is, the downward compression of wages in order to maintain competitiveness.

Let us elaborate on these mechanisms. EMU enlargement is expected to encourage a further flow of migration to Western Europe because transaction costs will be significantly reduced and wage differences between old and new members will become clearer (price transparency). As is already the case with immigration, this will result in a downward pressure on wages (due to increased labour supply) as well as pressures for the relaxation of employment benefits and their further deregulation. On the other hand, it can be claimed that the effects of eastern 
migration have already materialised and, if anything, with the accession of the CEECs to EMU we should expect a reversal of migration flows, especially if integration enhances the flow of capital to these countries and stabilises their economies further. Such trends are already evident in Europe, even outside EMU, for example the return of Polish and Bulgarian immigrants from Western Europe (Morris, 2008; Markova, 2009). Nevertheless, pressure on the labour markets of the existing Eurozone countries may continue even if migration abates - due to enhanced capital flows (either in the form of FDI or in the form of firm relocation) in the opposite direction (towards CEE). In essence, the mere threat of relocation will suffice to put pressure on the domestic labour markets to deregulate their industrial relations and raise their wage flexibility, as workers will be facing a dilemma between unemployment and employment flexibility. ${ }^{52}$

Therefore, in theory at least, it is possible that the future enlargement of EMU may lead to pressures for further flexibility in the labour markets of the existing memberstates. In fact, the anticipated pressures are real (not simply theoretical); but what is not certain is their actual size, since such pressures have to a large extent already been activated by the 2004 enlargement and the full liberalisation of product and capital markets between Eastern and Western Europe. In fact, in light of these pressures and the concerns regarding a possible downward convergence of regulation that they may cause, it is plausible to witness a process of further regulation of the labour market across the Eurozone and a more integrated coordination of employment policies. This can be achieved within the context of the EES and the wider orientation of the EU towards innovation and quality-based competition. As before, a lot depends on the political decisions that the countries participating in the EMU project will make: the economic pressures are there, but the policy outcomes are not exogenously given.

\footnotetext{
52 An important role in this direction is also played by supra-national regulations, such as the recent 'Services Directive', which could further erode labour relations pushing towards downward convergence of regulations (race to the bottom).
} 


\section{Concluding remarks}

The purpose of this paper was to provide a broad discussion of the various impacts that EMU has on the labour market. Mainly due to the fact that the issue of monetary integration has been the subject of polarised political views, a largely unfounded perception is widespread, that EMU inevitably leads to the deterioration of labour relations and the erosion of workers' rights throughout Europe. The perceived link between EMU and the monetarist and neo-liberal ideology (McNamara, 1998) cultivates this perception and prevents the critical examination of the labour market effects of monetary integration. Furthermore, in academic and policy debates alike, the issue is often examined on the basis of theoretical models (such as the OCA theory) that tend to understate the significance of a multitude of factors that may be exerting distinct influences on the European labour markets (not least relating to the political dimension of economic governance in the EU, its politics and institutions). In doing so, too little attention is paid to mechanisms and processes that can counter the pressure for a universal deregulation of industrial relations and attainment of maximum levels of labour market flexibility.

Although the pressures for enhanced flexibility in a monetary union are indeed significant, in our analysis we were able to identify and discuss a variety of other factors affecting labour markets in the post-EMU era - and the arguments concerning the further regulation or deregulation of the European labour markets deriving from these. We started with the central theoretical debate, concerning the OCA theory and its arguments in favour of enhancing labour mobility and wage flexibility. We saw that the arguments stemming from the OCA theory have significant analytical weight; but we also saw that they do not necessarily imply the universal deregulation of industrial relations. On the contrary, we argued that what they seem to require is selective and targeted regulation, aiming, on the one hand, at enhancing the adaptability of national economies inside the Eurozone and, on the other, preserving and increasing their competitiveness. Subsequently, we considered a number of other factors and processes, such as the shift of the basic pillars of macroeconomic policy in EMU and the ad hoc decentralisation of collective bargaining that 
it entails; the internalisation (embeddedness) of the logic of price stability; the budgetary constraints arising from the Stability and Growth Pact; and the institutional framework for the coordination of employment policies. We discussed how such factors lead to the need for qualitative labour market reforms in Europe, sometimes pushing towards greater flexibility and sometimes reinforcing the need for regulation and security in the labour market.

Ultimately, the aggregate impact of EMU on the European labour markets is difficult to establish theoretically and to measure empirically. A number of exogenous factors, which we were not able to discuss here, but the pressure of which is increasingly being felt across the globe, ${ }^{53}$ determine both the size of the pressures for flexibilisation and the member-states' ability to respond to these pressures. In any case, the accumulated experience of national reforms and transnational policy coordination, as briefly analysed in the third section of this paper, does not demonstrate a link between EMU and an unbridled deregulation of labour markets. If anything, in the post-EMU era we are witnessing a decline in the intensity of labour deregulation. We highlighted two reasons for this trend: first, the reform activism that preceded the introduction of the Euro and the reform fatigue of the electorate; second, but perhaps more importantly, the belief that universal deregulation leads to a race to the bottom and therefore to a qualitative downgrading of Europe's greatest competitive advantages, namely human capital and social protection.

This is the observation with which we wish to conclude this paper. EMU is a radical innovation in Europe, which creates the conditions for fundamental improvements in its international competitiveness and hence the quality of life of its citizens. The current financial and economic crisis and the resilience that the EMU countries have shown to it, despite the current problems faced by Greece, is enough to make us

53 The uncertainty and instability of the international financial system, under the current financial crisis is an obvious candidate - especially as it increases precariousness in the labour market and leads to an unprecedented erosion of asset values (including pensions). However, a number of perhaps more permanent factors had already emerged well before this financial crisis. These include globalisation, technological innovation, Europe's demography, illegal immigration, the increasing importance of the four major emerging markets (Brazil, Russia, India and China), energy security, and climate change. 
realize the tremendous costs and consequences that the incomplete integration of the European economies (with the existence of twelve or fifteen separate national currencies in a single market) would have for the European economy. At the same time, however, the adoption of the single currency and the establishment of a common monetary policy create pressures that necessitate comprehensive reforms and, to some extent at least, harmonisation of employment policies and labour market regulations across the EU. These pressures are real, but so is the room for manoeuvre across a range of policy options. What is more, these options are essentially political and not irrevocably constrained by exogenous factors and technocratic parameters. With the creation of EMU, Europe simply came closer to a fundamental dilemma, which it would have to address anyway, collectively or nationally, within the context of globalisation: on the one hand, to enhance the adaptability of its economy and of the functioning of its adjustment mechanisms; on the other hand, to strengthen the competitiveness of its economy, through the qualitative upgrading of all productive factors, including labour, and the development of its comparative advantages. Both challenges require a creative reform of industrial relations and of the labour market more generally. But, as noted above, the options for responding to these challenges are not bound irrevocably by the adoption of the common currency. 


\section{References}

Acocella N., Bartolomeo G. and Tirelli P. (2007), Fiscal Leadership and Coordination in the EMU, Open Economies Review, Vol.18, No3, pp.281-289.

Advagic S., Rhodes M. and Visser J. (2005), The emergence and evolution of social pacts, EUROGOV Paper No05-01.

Alesina A., Ardagna S. and Trebbi F. (2006), Who Adjusts and When? On the Political Economy of Reforms, NBER Working Paper No12049.

Amable, B. (2003) The Diversity of Modern Capitalism, Oxford University Press, Oxford.

Arnold C. and Cameron D. (2001), Why the EU developed the European Employment Strategy: unemployment, public opinion and member state preferences, paper presented at the Annual Meeting of the American Political Science Association, San Francisco, USA.

Auer P. (ed) (2002), Changing labour markets in Europe, ILO, Geneva.

Barnard, C. and Deakin, S. (2000) In search of coherence: social policy, the single market and fundamental rights. Industrial Relations Journal, Vol. 31, No4, pp.332-345.

Barr N. (ed) (1994), Labour Markets and Social Policy in Central and Eastern Europe: the transition and beyond, Oxford University Press, Oxford.

Barr N. (ed) (2005), Labour Markets and Social Policy: the accession and beyond, The World Bank, Washington DC.

Barrell R. and Dury K. (2001), Asymmetric Labour Markets in a Converging Europe: do differences matter?, ENEPRI Working Paper No2, Centre for European Policy Studies, Brussels.

Barro R. and Gordon D. (1983), Rules, discretion and reputation in a model of monetary policy, Journal of Monetary Economics, Vol.12, pp.101-121.

Bean C. (1998), The Interaction of Aggregate Demand Policies and Labour Market Reform, Swedish Economic Policy Review, Vol. 5/2.

Begg I. (2002), EMU and Employment, Working Paper No42, ESRC 'One Europe or Several?' Programme, University of Sussex.

Bercusson B. (1994), The Dynamic of European Labour Law after Maastricht, Industrial Law Journal Vol.23, No1, pp.1-31.

Bercusson B. (1995), The Collective Labour Law of the European Union, European Law Journal, Vol.1, No2, pp.157-179.

Berthold N. and Fehn R. (1998), Does EMU help promote labour-market reforms?, Kyklos, Vol.51, No4, pp.509-536.

Bertola G. and Boeri T. (2002), EMU Labour Markets Two Years on: Microeconomic Tensions and Institutional Evolution, in M. Buti and A. Sapir (eds), EMU and Economic Policy in Europe, Edward Elgar, Cheltenham. 
Bertola G., Boeri T. and Nicoletti G. (eds) (2001), Welfare and Employment in a United Europe, MIT Press, Cambridge MA.

Bioacain R. and Engels C. (1995), European Labour Law, Kluwer, Deventer.

Boeri T. (2004), Euro Adoption and the Labour Market, paper presented at the $10^{\text {th }}$ Dubrovnik Economic Conference, Dubrovnik, Croatia.

Boeri T. and Garibaldi P. (2006), Are labour markets in the new member states sufficiently flexible for EMU?, Journal of Banking and Finance, Vol. 30, pp.1393-1407.

Boeri T. and Terrell K. (2002), Institutional determinants of labour reallocation in transition, Journal of Economic Perspectives, Vol.16, No2, pp.51-76.

Bredgaard T., Larsen F. and Madsen P. (2005), The Flexible Danish Labour Market - A Review, Centre for Labour Market Research (CARMA) Research Paper No31, CARMA, Aalborg.

Buiter W. (2004), To Purgatory and Beyond: when and how should the accession countries from Central and Eastern Europe become full members of the EMU?, CEPR Discussion Paper No4342, Centre for Economic Policy Research, London.

Burda M. (1998), The Consequences of EU Enlargement for Central and East European Labour Markets, European Investment Bank Papers, Vol.3, pp.65-82.

Burda M. (1999), European Labour Markets and the Euro: how much flexibility do we really need?, CEPR Discussion Paper No2217, Centre for Economic Policy Research, London.

Calmfors L. (2001), Unemployment, Labour-Market Reform and Monetary Union, Journal of Labour Economics, Vol. 19, No2.

Calmfors L. and Driffill J. (1988), Bargaining Structure, Corporatism and Macroeconomic Performance, Economic Policy, Vol.6, No2.

Chalmers D. and Lodge M. (2003), The Open Method of Coordination and the European Welfare State, CARR Discussion Paper 11.

Chiattelli C. (2008), The Advocacy and Diffusion of EU Employment Policy: The European Employment Strategy in France and Italy, Unpublished PhD Thesis, LSE.

Clausen V. and Hayo B. (2006), Asymmetric monetary policy effects in EMU, Applied Economics, Vol.38, No10, pp.1123-1134.

Clements B., Kontolemis Z. and Levy J. (2001), Monetary Policy under EMU: differences in the transition mechanism?, IMF Working Paper No01/102.

COM (2007a), Modernising Social Protection for Greater Social Justice and Economic Cohesion: taking forward the active inclusion of people furthest from the labour market, Communication from the Commission to the Council, European Commission, Brussels.

COM (2007b), Towards Common Principles of Flexicurity: more and better jobs through flexibility and security, Communication from the Commission to the European Parliament, the Council, the ESC and the Committee of the Regions, European Commission, Brussels.

Crouch C. and Streeck W. (eds) (1997), Political economy of modern capitalism: mapping convergence and diversity, Sage Publications, London. 
Cukierman A. and Lippi F. (1999), Central bank interdependence, centralization of wage bargaining, inflation and unemployment: theory and evidence, European Economic Review, Vol.43, pp.1395-1434.

De Grauwe P. (2006), What have we learnt about monetary integration since the Maastricht treaty?, Journal of Common Market Studies, Vol.44, No4, pp.711-730.

De Grauwe P. (2007), Economics of Monetary Union (7th edition), Oxford University Press, Oxford.

De Grauwe P. and Sénégas M. (2004), Asymmetries in Monetary Policy Transmission: Some Implications for EMU and Its Enlargement, Journal of Common Market Studies, Vol.42, No1, pp.753-773.

De la Porte C. (2002), Is the Open Method of Coordination Appropriate for Organising Activities at European Level in Sensitive Policy Areas?, European Law Journal, Vol.8, No1, pp.38-58.

Dickens W., Goette L., Groshen E., Holden S., Messina J., Scheitzer M., Turunen J. and WardWarmedinger M. (2006), How Wages Change: Micro Evidence from the International Wage Flexibility Project, ECB Working Paper No 697, European Central Bank, Frankfurt.

Donaghey J. and Teague P. (2005), The persistence of social pacts in Europe, Industrial Relations Journal, Vol.36, No6, pp.478-493.

Driffill, J. (2006), The Centralization of Wage Bargaining Revisited, Journal of Common Market Studies, Vol.44, No4, pp.731-756.

Duval R. and Elmeskov J. (2006), The effects of EMU on structural reforms in labour and product markets, ECB Working Paper No596, European Central Bank, Frankfurt.

Dyson K. and Featherstone K. (1999), The Road to Maastricht: Negotiating Economic and Monetary Union, Oxford University Press, Oxford.

Eichener V. (1997), Effective European Problem-Solving: Lessons from the Regulation of Occupational Safety and Environmental Protection, Journal of European Public Policy, Vol. 4, No4, pp.591-608.

Eichengreen B. (1998), European Monetary Union: a Tour d'Horizon, Oxford Review of Economic Policy, Vol.14, No3, pp.24-40.

Elmeskov J. and MacFarlan M. (1993), Unemployment Persistence, OECD Economic Studies, Vol.21, pp.59-88.

Enderlein H. (2006), Adjusting to EMU: The Impact of Supranational Monetary Policy on Domestic Fiscal and Wage-Setting Institutions, European Union Politics, Vol.7, No1, pp.113140 .

Esping-Andersen, G. (1990). The Three Worlds of Welfare Capitalism, Polity Press, Cambridge.

Fagan, C., Grimshaw D., Rubery, J. (2006) The subordination of the gender equality objective: the National Reform Programmes and 'making work pay' policies, Industrial Relations Journal, Vol.37, No6, pp. 571-592.

Falkner G., Treib O., Hartlepp M. and Leiber S. (2005), Complying with Europe? EU Minimum Harmonisation and Soft Law in the Member States, Cambridge University Press, Cambridge. 
Farina F. and Tamborini R. (2004), Set a Sufficiently Ambitious Budget Target and Let the Automatic Stabilizers Work - Will it really Work in the European Monetary Union?, Open Economies Review, Vol.15, No2, pp.143-168.

Ferrera M. (1996), The southern model of welfare in social Europe, Journal of European Social Policy, Vol.6, No1, pp.17-37.

Geyer R. (2000), Exploring European Social Policy, Polity Press, Cambridge.

Giavazzi F. and Pagano M. (1988), The Advantage of Tying One's Hands: EMS Discipline and Central Bank Credibiliy, European Economic Review, Vol.32, pp.1055-1075.

Goetschy J. (1999), The European Employment Strategy: genesis and development, European Journal of Industrial Relations, Vol.5, No2, pp.117-137.

Hall P. and Franzese R. (1998), Mixed Signals: Central Bank Independence, Coordinated Wage Bargaining and European Monetary Union, International Organization, Vol.52, No3, pp.505536.

Hancké B. and Rhodes M. (2005), EMU and Labour Market Institutions in Europe: The Rise and Fall of National Social Pacts, Work and Occupations, Vol.32, No2, pp.196-228.

Hancké B. and Soskice D. (2003), Wage-setting and inflation targets in EMU Oxford Review of Economic Policy. Vol.19, No1, pp.149-160.

Hancke B., Rhodes M. and Thatcher M. (eds) (2007), Beyond Varieties of Capitalism: Conflict, contradiction and complementarities in the European Economy, OUP, Oxford.

Hefeker C. (2006), EMU Enlargement, Policy Uncertainty and Economic Reforms, CESifo Working Paper No1767.

Heidenreich M. and Zeitlin J. (eds) (2009), Changing European Employment and Welfare Regimes: The Influence of the Open Method of Coordination on National Reforms, EUI Studies in the Political Economy of Welfare, Routledge, London (forthcoming).

HMT (2003a), EMU and labour market flexibility, EMU Study, HM Treasury, London.

HMT (2003b), EMU and the monetary transmission mechanism, EMU Study, HM Treasury, London.

Hodson D. and Maher I. (2001), The Open Method of Co-ordination as a New Mode of Governance: The Case of Soft Economic Policy CO-ordination, Journal of Common Market Studies, Vol.39, No4, pp.719-746.

Hoj J., Galasso V., Nicoletti G. and Dang T. (2006), The Political Economy of Structural Reform: Empirical Evidence from OECD Countries, OECD Economics Department Working Paper No501.

Hoskyns C. (1996), Integrating Gender: Women, Law and Politics in the European Union, Verso, London.

Hughes-Hallet A. and Lewis J. (2004), How successful has the stability and growth pact been?: an empirical analysis, Quarterly Journal of Economic Research, Vol.73, pp.392-404.

Hughes-Hallet A. and Viegi N. (2003), Labour Market Reform and the Effectiveness of Monetary Policy in the EMU. Journal of Economic Integration, Vol.18, No4, pp.726-749. 
Hughes-Hallett A. and Jensen S. (2003), On the Role of Labour Market Reform for the Enlargement of a Monetary Union, CESifo Economic Studies.

IMF (2004), Fostering structural reforms in industrial countries, ch.3 in World Economic Outlook, Washington DC: International Monetary Fund.

James P. (1993), Occupational Health and Safety, in M. Gold (ed), The Social Dimension: Employment Policy in the European Community. Macmillan, London.

Kenen P. (1969), The Optimum Currency Area: An Eclectic View, in R. Mundell and H. Swoboda (eds), Monetary Problems of the International Economy, University of Chicago Press, Chicago.

Kenner J. (2003), EU Employment Law: From Rome to Amsterdam and Beyond, Hart, Oxford.

Kydland F. and Prescott E. (1977). Rules rather than discretion: the inconsistency of optimal plans, Journal of Political Economy, Vol.85, pp.473-492.

Larsson A. (1998), The European Employment Strategy and the EMU: you must invest to save, Economic and Industrial Democracy, Vol.19, No3, pp.391-415.

Lauer C. (1999), The Effects of European Economic and Monetary Union on Wage Behaviour, IZA Discussion Paper No36.

Layard R, Jackman R and Nickell S. (1991), Unemployment, Oxford University Press, Oxford.

Leibfried S. (2005), European Social Policy: Left to Judges and the Market?, in H. Wallace, W. Wallace and M. Pollack (eds), Policy-making in the European Union, Oxford University Press, Oxford.

Leibfried S. and Pierson P. (2000), Social Policy: left to courts and markets?, in H. Wallace and W. Wallace (eds), Policy Making in the European Union, Oxford University Press, Oxford.

Leiner-Killinger N., López-Pérez V., Stiegert R. and Vitale G. (2007), Structural reforms in EMU and the role of monetary policy: a survey of the literature, ECB Occasional Paper No66, European Central Bank, Frankfurt.

Markova E. (2009), Optimising Migration Effects: Bulgaria - the sending country perspective, GreeSE Paper No22, Hellenic Observatory, LSE.

Martin A. (1999), Wage Bargaining under EMU: Europeanization, Re-Nationalization, or Americanization?, Center for European Studies Working Paper No99.01.03, Harvard University.

Mazey S. (1998), The European Union and Women's Rights: From the Europeanization of National Agendas to the Nationalization of a European Agenda?, Journal of European Public Policy, Vol.5, No1, pp.131-152.

McKinnon R. (1963), Optimum Currency Areas, American Economic Review, Vol.52, pp.717-725.

McNamara K. (1998), The Currency of Ideas, Cornell University Press.

Monastiriotis V. (2005), Labour Market Flexibility in the UK: regional variations and the role of global/local forces, Economic and Industrial Democracy, Vol.26, No3, pp.445-478. 
Monastiriotis V. (2007), Union Retreat and Regional Economic Performance: the UK experience, Regional Studies, Vol.41, No2, pp.143-156.

Mongelli F. (2002), "New" views on the Optimum Currency Area theory: what is EMU telling us?, ECB Working Paper No138, European Central Bank, Frankfurt.

Morris N. (2008), Tide of migration turns as Polish workers return, The Independent (Wednesday, 27 February).

Mundell R. (1961), A Theory of Optimum Currency Areas, American Economic Review, Vol.51, pp.657-665.

Mundell R. (1973), Uncommon Arguments for Common Currencies, in H. Johnson and A. Swoboda (eds), The Economics of Common Currencies, Allen and Unwin, New York.

Nickell S. And Quintini G. (2003), Nominal wage rigidity and the rate of inflation, Economic Journal, Vol.113(490), pp.762-781.

OECD (1994), The OECD Jobs Study: Evidence and Explanations, OECD, Paris.

OECD (1996), The OECD Jobs Strategy: Pushing Ahead with the Strategy, OECD, Paris.

OECD (1999), Employment Outlook 1999, OECD, Paris.

OECD (2006), Employment Outlook 2006, OECD, Paris.

Raveaud G. (2007), The European Employment Strategy: Towards More and Better Jobs?, Journal of Common Market Studies, Vol. 45, No. 2, pp. 411-434.

Regent S. (2003), The Open Method of Co-ordination: A New Form of Supranational Governance?, European Law Journal, Vol.9, No2, pp.190-214.

Regini M. and Esping-Andersen G. (eds) (2000), Why deregulate labour markets?, OUP, Oxford.

Rhodes M. (2005), Employment Policy: Between Efficacy and Experimentation, in H. Wallace, W. Wallace and M. Pollack (eds), Policy-Making in the European Union, Oxford University Press, Oxford.

Rubery, J. (2002) 'Gender Mainstreaming and Gender Equality in the EU: the impact of the EU employment strategy', Industrial Relations Journal , Vol.33, 500-522

Schelkle W. (2001), The Optimum Currency Area Approach to European Monetary Integration: Framework of Debate or Dead End?, South Bank European Paper No2, South Bank University, London.

Schelkle W. (2004), Anchoring Reform by Subordinating to Hegemony? The Political Economy of EMU Enlargement, paper presented at the Annual Meeting of the International Studies Association, Montreal, Canada.

Schelkle W. (2005), The Political Economy of EMU Policy Coordination: From Disciplinarian Device to Insurance Arrangement?, Journal of Common Market Studies, Vol.43, No.2, pp.371391.

Schelkle W. (2009), Good governance in crisis or a good crisis for governance? A comparison of the EU and the US, LEQS Paper No16, European Institute, LSE. 


\section{Beyond the crisis}

Shaw J. (ed) (2000), Social Law and Policy in an Evolving European Union. Hart, Oxford.

Sibert A. and Sutherland A. (2000), Monetary union and labour market reform, Journal of International Economics, Vol.51, pp.421-435.

Soltwedel R., Dohse D. and Krieger-Boden C. (2000), European Labour Markets and EMU: challenges ahead, Finance and Development, Vol.37, No2, IMF.

Soskice D. and Iversen T. (1998), Multiple Wage-Bargaining Systems in the Single European Currency Area, Oxford Review of Economic Policy, Vol.14, No3, pp.110-124.

Talani L. (2004), European Political Economy: Political Science Perspectives, Ashgate, London.

Tinsley D. and Monastiriotis V. (2007), Developing an Index of Labour Market Adaptability for the UK, DTI Employment Relations Research Series No.85, Department of Trade and Industry, UK.

Traxler F. (1999), Employers and employer organisations: the case of governability, Industrial Relations Journal, Vol.30, No4, pp.345-354.

Trubek D. and Mosher J. (2003), New Governance, Employment Policy, and the European Social Model, in J. Zeitlin and D. Trubek (eds), Governing Work and Welfare in a New Economy, Oxford University Press, Oxford.

Turner D. and Seghezza E. (1999), Testing for a common OECD Phillips curve, Working Paper No219, Economics Department, OECD, Paris.

Vinals J. and Jimeno J. (1998), The impact of EMU on unemployment, European Investment Bank Papers, Vol.3, pp.83-97.

Vos E. (1999), Institutional Frameworks of Community Health and Safety Legislation: Committees, Agencies and Private Bodies, Hart, Oxford.

Zeitlin J. and Pochet P. (eds) with L. Magnusson (2005), The Open Method of Co-ordination in Action: The European Employment and Social Inclusion Strategies, P.I.E-Peter Lang, Bruxelles. 


\section{Recent LEQS papers}

Lütz, Susanne \& Kranke, Matthias. 'The European Rescue of the Washington Consensus? EU and IMF Lending to Central and Eastern European Countries.' LEQS Paper No. 22, May 2010

Hartlapp, Miriam; Metz, Julia \& Rauh, Christian. 'The agenda set by the EU Commission: the result of balanced or biased aggregation of positions?' LEQS Paper No. 21, April 2010

Costa-i-Font, Joan. 'Unveiling Vertical State Downscaling: Identity and/or the Economy?' LEQS Paper No. 20, March 2010

Delanty, Gerard. 'The European Heritage from a Critical Cosmopolitan Perspective. LEQS Paper No. 19, February 2010

Outhwaite, William. 'Europe at 21: Transitions and Transformations since 1989'. LEQS Paper No. 18, January 2010

Lavdas, Kostas A..'Normative Evolution in Europe: Small States and Republican Peace'. LEQS Paper No. 17, January 2010

Schelkle, Waltraud. 'Good governance in crisis or a good crisis for governance? A comparison of the EU and the US'. LEQS Paper No. 16, December 2009

Keating, Michael. 'Second Round Reform. Devolution and constitutional reform in the United Kingdom, Spain and Italy'. LEQS Paper No. 15, December 2009

Hyman, Richard. 'Trade Unions and 'Europe': Are the Members out of Step?'. LEQS Paper No. 14, November 2009

Dani, Marco. 'Economic and social conflicts, integration and constitutionalism in contemporary Europe'. LEQS Paper No. 13, November 2009

Rodríguez-Pose, Andrés \& Krøijer, Anne. 'Fiscal Decentralization and Economic Growth in Central and Eastern Europe'. LEQS Paper No. 12, October 2009

Cheshire, Paul C. \& Magrini, Stefano. 'Urban Growth Drivers and Spatial Inequalities: Europe - a Case with Geographically Sticky People. LEQS Paper No. 11, October 2009

McCrea, Ronan. 'The Recognition of Religion within the Constitutional and Political Order of the European Union'. LEQS Paper No. 10, September 2009

Bertola, Guiseppe \& Mola, Lorenza. 'Services Provision and Temporary Mobility: Freedoms and Regulation in the EU' LEQS Paper No. 9, September 2009

Walker, Neil. 'Multilevel Constitutionalism: Looking Beyond the German Debate'. LEQS Paper No. 8, June 2009

Frankel, Jeffrey. 'The Estimated Trade Effects of the Euro: Why Are They Below Those From Historical Monetary Unions Among Smaller Countries?'. LEQS Paper No. 7, June 2009

Colomer, Josep M.. 'On Building the American and the European Empires'. LEQS Paper No. 6, June 2009

Boeri, Tito. 'Immigration to the Land of Redistribution'. LEQS Paper No. 5, June 2009

Jones, Erik. 'They Have No Idea... Decision-making and Policy Change in the Global Financial Crisis'. LEQS Paper No. 4, May 2009

Frey, Bruno. 'A New Concept of European Federalism'. LEQS Paper No. 3, May 2009

Chalmers, Damian. 'Gauging the Cumbersomeness of EU Law'. LEQS Paper No. 2, May 2009

Bellamy, Richard. 'The Liberty of the Post-Moderns? Market and Civic Freedom within the EU'. LEQS Paper No. 1, May 2009 


\section{LEQS}

European Institute

London School of Economics

Houghton Street

WC2A 2AE London

Email: euroinst.LEQS@lse.ac.uk

http://www2.lse.ac.uk/europeanInstitute/LEQS/Home.aspx 